\title{
WRF-Chem simulated surface ozone over south Asia during the pre-monsoon: effects of emission inventories and chemical mechanisms
}

\author{
Amit Sharma ${ }^{1,2}$, Narendra Ojha ${ }^{2}$, Andrea Pozzer ${ }^{2}$, Kathleen A. Mar ${ }^{3}$, Gufran Beig ${ }^{4}$, Jos Lelieveld ${ }^{2,5}$, and \\ Sachin S. Gunthe ${ }^{1}$ \\ ${ }^{1}$ Department of Civil Engineering, Indian Institute of Technology Madras, Chennai, India \\ ${ }^{2}$ Atmospheric Chemistry Department, Max Planck Institute for Chemistry, Mainz, Germany \\ ${ }^{3}$ Institute for Advanced Sustainability Studies, Potsdam, Germany \\ ${ }^{4}$ Indian Institute for Tropical Meteorology, Pune, India \\ ${ }^{5}$ Energy, Environment and Water Research Center, The Cyprus Institute, Nicosia, Cyprus
}

Correspondence to: Amit Sharma (amit.iit87@gmail.com) and Narendra Ojha (narendra.ojha@mpic.de)

Received: 1 December 2016 - Discussion started: 9 December 2016

Revised: 28 October 2017 - Accepted: 2 November 2017 - Published: 5 December 2017

\begin{abstract}
We evaluate numerical simulations of surface ozone mixing ratios over the south Asian region during the pre-monsoon season, employing three different emission inventories in the Weather Research and Forecasting model with Chemistry (WRF-Chem) with the second-generation Regional Acid Deposition Model (RADM2) chemical mechanism: the Emissions Database for Global Atmospheric Research - Hemispheric Transport of Air Pollution (EDGARHTAP), the Intercontinental Chemical Transport Experiment phase B (INTEX-B) and the Southeast Asia Composition, Cloud, Climate Coupling Regional Study (SEAC4RS). Evaluation of diurnal variability in modelled ozone compared to observational data from 15 monitoring stations across south Asia shows the model ability to reproduce the clean, rural and polluted urban conditions over this region. In contrast to the diurnal average, the modelled ozone mixing ratios during noontime, i.e. hours of intense photochemistry (11:3016:30 IST - Indian Standard Time - UTC + 5:30), are found to differ among the three inventories. This suggests that evaluations of the modelled ozone limited to $24 \mathrm{~h}$ average are insufficient to assess uncertainties associated with ozone buildup. HTAP generally shows $10-30$ ppbv higher noontime ozone mixing ratios than SEAC4RS and INTEX-B, especially over the north-west Indo-Gangetic Plain (IGP), central India and southern India. The HTAP simulation repeated with the alternative Model for Ozone and Related Chemical Tracers (MOZART) chemical mechanism showed even more
\end{abstract}

strongly enhanced surface ozone mixing ratios due to vertical mixing of enhanced ozone that has been produced aloft. Our study indicates the need to also evaluate the $\mathrm{O}_{3}$ precursors across a network of stations and the development of highresolution regional inventories for the anthropogenic emissions over south Asia accounting for year-to-year changes to further reduce uncertainties in modelled ozone over this region.

\section{Introduction}

Tropospheric ozone plays central roles in atmospheric chemistry, air quality and climate change. Unlike primary pollutants, which are emitted directly, tropospheric ozone forms photochemically, involving precursors such as carbon monoxide (CO), volatile organic compounds (VOCs) and oxides of nitrogen $\left(\mathrm{NO}_{x}\right)$, supplemented by transport from the stratosphere (e.g. Crutzen, 1974; Atkinson, 2000; Monks et al., 2015). It can be transported over long distances resulting in enhanced concentrations even in areas remote from the sources of precursors (Cox et al., 1975). The photochemical production of ozone and its impacts on agricultural crops and human health are especially pronounced near the surface. Numerous studies have shown that elevated surface ozone levels significantly reduce crop yields (e.g. Krupa 
et al., 1998; Emberson et al., 2009; Ainsworth et al., 2012; Wilkinson et al., 2012), in addition to having adverse human health effects that cause premature mortality (e.g. Bell et al., 2004; Jerrett et al., 2009; Anenberg et. al., 2010; Lelieveld et al., 2015).

An accurate representation of anthropogenic emissions of ozone precursors is essential to understand the photochemical production of ozone and support policy making. While anthropogenic emissions have been nearly stable or decreasing over North America and Europe (e.g. Yoon and Pozzer, 2014), there has been substantial enhancement over the east and south Asian regions in recent decades (e.g. Akimoto, 2003; Ohara et al., 2007; Logan et al., 2012; Gurjar et al., 2016). The number of premature mortalities per year due to outdoor air pollution is anticipated to double by the year 2050 as compared to the year 2010 in a business-as-usual scenario, predominantly in Asia (Lelieveld et al., 2015). The multipollutant index over all populated regions in the Northern Hemisphere shows a general increase, with south Asia being the major hotspot of deteriorating air quality (Pozzer et al., 2012).

The growth of anthropogenic emissions over south Asia has regional implications and is also predicted to influence air quality on a hemispheric scale (Lelieveld and Dentener, 2000). It was shown that the anthropogenic emissions and their subsequent photochemical degradation over south Asia influence air quality over the Himalayas (e.g. Ojha et al., 2012; Sarangi et al., 2014) and the Tibetan Plateau (Lüthi et al., 2015) as well as the marine environment downwind of India (e.g. Lawrence and Lelieveld, 2010). Additionally, the prevailing synoptic-scale weather patterns make this region highly conducive to long-range export of pollutants (e.g. Lelieveld et al., 2002; Lawrence et al., 2003; Ojha et al., 2014; Zanis et al., 2014). Therefore, the accurate estimation of anthropogenic emissions over south Asia and their representation in chemical transport models are essential to quantify the effects on regional as well as global air quality.

The Weather Research and Forecasting model with Chemistry (WRF-Chem) (Grell et al., 2005; Fast et al., 2006), a regional simulation system, has been popular for use over the south Asian region in numerous recent studies to simulate the meteorology and spatiotemporal distribution of ozone and related trace gases (e.g. Kumar et al., 2012a, b; Michael et al., 2013; Gupta et al., 2015; Jena et al., 2015; Ansari et al., 2016; Ojha et al., 2016; Girach et al., 2017). WRF-Chem simulations at higher spatial resolution employing regional emission inventories have been shown to better reproduce the observed spatial and temporal heterogeneities in ozone over this region as compared to the global models (e.g. Kumar et al., 2012b; Ojha et al., 2016). However, an evaluation of modelled ozone based on data from a network of stations across south Asia is imperative considering very large spatiotemporal heterogeneity in the distribution of ozone over this region (e.g. Kumar et al., 2010; Ojha et al., 2012; Kumar et al., 2012b) mainly resulting from heterogeneous precur- sor sources and population distribution. WRF-Chem simulated ozone distributions have also been utilized to assess the losses in crop yields, and it was suggested that the estimated crop losses would be sufficient to feed about 94 million people living below the poverty line in this region (Ghude et al., 2014). Further, WRF-Chem has been used to estimate that premature mortality rate in India caused by chronic obstructive pulmonary disease (COPD) due to surface $\mathrm{O}_{3}$ exposure was $\sim 12000$ people in the year 2011 (Ghude et al., 2016). Despite these applications, there is room for improvement in modelled concentrations, as some limited studies evaluating ozone on diurnal scales revealed a significant overestimation of noontime ozone, e.g. by as much as 20 ppbv in Kanpur (Michael et al., 2013) and 30 ppbv in Delhi (Gupta and Mohan, 2015).

Using WRF-Chem, Amnuaylojaroen et al. (2014) showed that over continental southeast Asia surface ozone mixing ratios vary little $(\sim 4.5 \%)$ among simulations employing different emission inventories. A recent study by Mar et al. (2016) highlighted the dependence of WRF-Chem predicted ozone air quality (over Europe) on the chosen chemical mechanism. These results indicate the need for evaluating the effects of emission inventories and chemical mechanisms on the model performance using a network of stations across south Asia, which has not been carried out thus far. The main objectives of the present study are

a. to evaluate WRF-Chem simulated ozone over south Asia, especially the diurnal variability, against recent in situ measurements from stations representing different chemical environments (urban, rural, clean, etc.);

b. to intercompare model-simulated $\mathrm{O}_{3}$ among different emission inventories; and

c. to intercompare model-simulated $\mathrm{O}_{3}$ between two extensively used chemical mechanisms (Model for Ozone and Related Chemical Tracers - MOZART, and the second-generation Regional Acid Deposition Model RADM2) with the same emission inventory.

We focus on the pre-monsoon season (March-May) for the study, as $\mathrm{O}_{3}$ mixing ratios at the surface are generally the highest over most of south Asia during this period (Jain et al., 2005; Debaje et al., 2006; Reddy et al., 2010; Ojha et al., 2012; Gaur et al., 2014; Renuka et al., 2014; Bhuyan et al., 2014; Sarangi et al., 2014; Yadav et al., 2014; Sarkar et al., 2015). This is because photochemistry over south Asia is most intense during this season due to the combined effects of high pollution loading, biomass-burning emissions and a lack of precipitation. The effects of biomass burning on ozone in southern Asia have been studied by Jena et al. (2014), reporting $\mathrm{O}_{3}$ enhancements of 4-10 ppb (25$50 \%)$ in the eastern region including Burma, 1-3 ppb (10$25 \%)$ in central India and 1-7 ppb (4-10\%) in the IndoGangetic region. Further, the $\mathrm{O}_{3}$ enhancement was found to 
be about 2-6 ppb (8-20\%) over the Bay of Bengal in March, which was attributed to transport from the eastern region. Section 2 presents the model description, including physics and chemistry options, emission inputs and the observational data. Model evaluation focussing on the effects of different emission inventories on ozone is presented in Sect. 3. The intercomparison between the RADM2 and MOZART chemical mechanisms is discussed in Sect. 4. The subregional and south Asian domain evaluation and recommendations on model configuration are provided in Sect. 5, followed by the summary and conclusions drawn from the study in Sect. 6 . The abbreviations and acronyms used in this paper are listed in Table 1.

\section{Methodology}

\subsection{WRF-Chem}

In this study, we use the Weather Research and Forecasting model coupled with chemistry (WRF-Chem version 3.5.1), which is an online mesoscale model capable of simulating meteorological and chemical processes simultaneously (Grell et al., 2005; Fast et al., 2006). The model domain (Fig. 1) is defined on a Mercator projection and is centred at $22^{\circ} \mathrm{N}, 83^{\circ} \mathrm{E}$ with 274 and 352 grid points in the eastwest and north-south directions, respectively, at the horizontal resolution of $12 \mathrm{~km} \times 12 \mathrm{~km}$. The land use dataset is incorporated from the US Geological Survey (USGS) based on 24 land use categories. The ERA-Interim reanalysis dataset from ECMWF (http://www.ecmwf.int/en/research/ climate-reanalysis/browse-reanalysis-datasets), archived at the horizontal resolution of about $0.7^{\circ}$ and temporal resolution of $6 \mathrm{~h}$, is used to provide the initial and lateral boundary conditions for the meteorological calculations. All simulations in the study have been conducted for the period of 26 February-31 May 2013 at a time step of 72 s. The model output is stored every hour for analysis. The first 3 days of model output have been discarded as model spin-up.

Radiative transfer in the model has been represented using the Rapid Radiative Transfer Model (RRTM) longwave scheme (Mlawer, 1997) and the Goddard shortwave scheme (Chou and Suarez, 1994). Surface physics is parameterized using the unified Noah land surface model (Tewari et al., 2004) along with ETA similarity option (Monin and Obukhov, 1954; Janjic, 1994, 1996), and the planetary boundary layer (PBL) is based on the Mellor-Yamada-Janjic (MYJ) scheme (Mellor and Yamada, 1982; Janjic, 2002). The cloud microphysics is represented by the Lin et al. scheme (Lin et. al., 1983), and cumulus convection is parameterized using the Grell 3-D ensemble scheme (Grell, 1993; Grell and Devenyi, 2002). Four-dimensional data assimilation (FDDA) is incorporated for nudging to limit the drift in the model-simulated meteorology from the ERA-Interim reanalysis (Stauffer and Seaman, 1990; Liu et al., 2008). Hor-

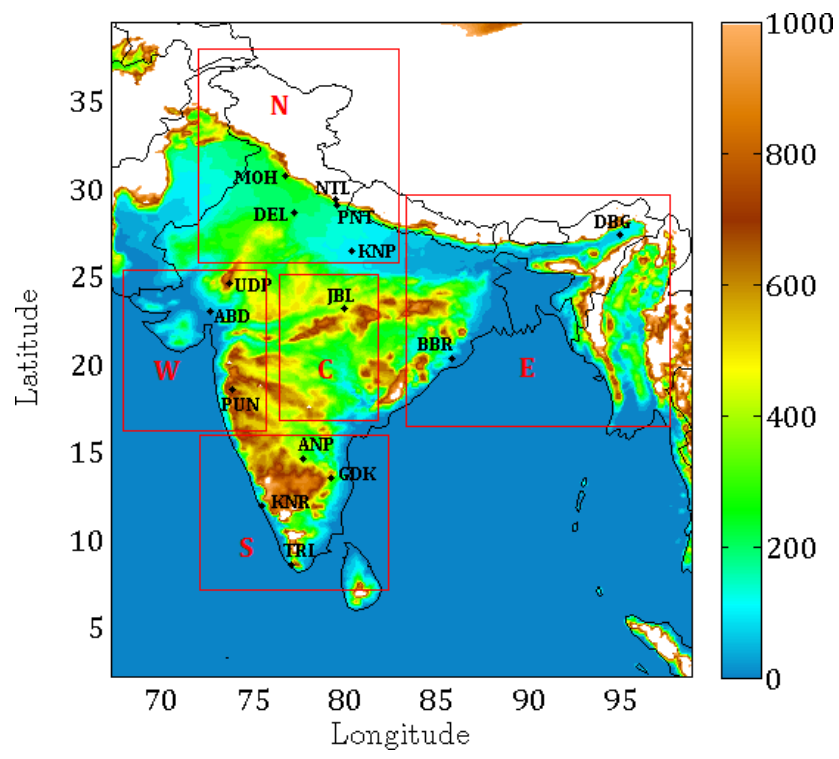

Figure 1. Simulation domain showing terrain height (in metres) and observation sites. The white region indicates that the terrain height is equal to or exceeds $1 \mathrm{~km}$. The domain is subdivided into five regions, i.e. North $(\mathrm{N})$, south $(\mathrm{S})$, east $(\mathrm{E})$, west $(\mathrm{W})$ and central $(\mathrm{C})$, as shown by red rectangles.

izontal winds are nudged at all vertical levels, whereas temperature and water vapour mixing ratios are nudged above the PBL (Stauffer et al., 1990, 1991). The nudging coefficients for temperature and horizontal winds are set as $3 \times 10^{-4} \mathrm{~s}^{-1}$ and as $10^{-5} \mathrm{~s}^{-1}$ for water vapour mixing ratio (Otte, 2008).

This study utilizes two different chemical mechanisms: RADM2 (Stockwell et al., 1990) and MOZART-4 (Emmons et al., 2010). RADM2 chemistry includes 63 chemical species participating in 136 gas-phase and 21 photolysis reactions. MOZART chemistry includes 81 chemical species participating in 159 gas-phase and 38 photolysis reactions. Aerosols are represented using the Modal Aerosol Dynamics Model for Europe/Secondary Organic Aerosol Model (MADE/SORGAM) (Ackermann et al., 1998; Schell et al., 2001) with RADM2 and Global Ozone Chemistry Aerosol Radiation and Transport (GOCART) (Chin et al., 2000) with MOZART. The photolysis rates are calculated using the Fast-J photolysis scheme (Wild et al., 2000) in the RADM2 simulations and the Madronich Fast Tropospheric Ultraviolet-Visible (FTUV) scheme in the MOZART simulation. In WRF-Chem, the Madronich FTUV photolysis scheme uses climatological $\mathrm{O}_{3}$ and $\mathrm{O}_{2}$ overhead columns. The treatment of dry deposition process also differs between RADM2 and MOZART due to differences in Henry's law coefficients and diffusion coefficients. The chemical initial and lateral boundary conditions are provided from 6-hourly fields from MOZART-4/GEOS5 (http://www.acom.ucar.edu/ wrf-chem/mozart.shtml). 
Table 1. Abbreviations and acronyms.

\begin{tabular}{ll}
\hline EDGAR & Emissions Database for Global Atmospheric Research \\
HTAP & Hemispheric Transport of Air Pollution \\
IGP & Indo-Gangetic Plain \\
IST & Indian Standard Time \\
INTEX-B & Intercontinental Chemical Transport Experiment phase B \\
MB & Mean bias \\
MOZART & Model for Ozone and Related Chemical Tracers \\
NMB & Normalized mean bias \\
PBL & Planetary boundary layer \\
RMSD & Centred root mean square difference \\
RRTM & Rapid Radiative Transfer Model \\
SEAC4RS & Southeast Asia Composition, Cloud, Climate Coupling Regional Study \\
WRF-Chem & Weather Research and Forecasting model coupled with chemistry \\
\hline
\end{tabular}

\subsection{Emission inputs}

This study utilizes three different inventories for the anthropogenic emissions: the Emissions Database for Global Atmospheric Research - Hemispheric Transport of Air Pollution (EDGAR-HTAP), the Intercontinental Chemical Transport Experiment phase B (INTEX-B) and the Southeast Asia Composition, Cloud, Climate Coupling Regional Study (SEAC4RS), which are briefly described here. The HTAP inventory (Janssens-Maenhout et al., 2015) for anthropogenic emissions (http://edgar.jrc.ec.europa.eu/htap_v2/index.php? SECURE=_123) available for the year 2010 has been used. The HTAP inventory has been developed by complementing various regional emissions with EDGAR data, in which Asian region including India is represented by the Model Intercomparison Study for Asia (MICS-Asia) inventory, which is at a horizontal resolution of $0.25^{\circ} \times 0.25^{\circ}$ (Carmichael et al., 2008). The resultant global inventory is regridded at the spatial resolution of $0.1^{\circ} \times 0.1^{\circ}$ and temporal resolution of 1 month. HTAP includes emissions of $\mathrm{CO}, \mathrm{NO}_{x}, \mathrm{SO}_{2}$, nonmethane volatile organic compounds (NMVOCs), particulate matter (PM), black carbon (BC) and organic carbon (OC) from power, industry, residential, agriculture, ground transport and shipping sectors. The INTEX-B inventory (Zhang et al., 2009), developed to support the INTEX-B field campaign by the National Aeronautics and Space Administration (NASA) in spring 2006, is the second inventory used in this study. It provides total emissions for the year 2006 at a horizontal resolution of $0.5^{\circ} \times 0.5^{\circ}$. The emission sectors include power generation, industry, residential and transportation. The SEAC4RS inventory (Lu and Streets, 2012), prepared for the NASA SEAC4RS field campaign, is the third inventory used in this study. It provides total emissions for the year 2012 at a spatial resolution of $0.1^{\circ} \times 0.1^{\circ}$. SEAC4RS and INTEX-B did not cover regions in the north-western part of the domain, and therefore we complemented this region (longitude $<75^{\circ} \mathrm{E}$ and latitude $>25^{\circ} \mathrm{N}$ ) by HTAP emission data. The emissions of $\mathrm{CO}$, NMVOCs and $\mathrm{NO}_{x}$ emissions among the three emission inventories, as included in the simulations, are shown in Fig. 2. Table 2 provides estimates of total emissions over different regions (as defined in Fig. 1) from the three inventories. The total emissions over all regions show that HTAP has about $43 \%$ higher and SEAC4RS about $46 \%$ higher $\mathrm{NO}_{x}$ emissions compared to the INTEXB inventory. Also, HTAP has about $37 \%$ higher VOC emissions compared to SEAC4RS and about $49 \%$ higher compared to the INTEX-B inventory. Hence, SEAC4RS, the most recent inventory of the three, has similar total $\mathrm{NO}_{x}$ emissions to those in HTAP but the total VOC source is closer to INTEX-B, which is the oldest of the three inventories. Considering the non-linear dependence of $\mathrm{O}_{3}$ formation on precursors, numerical experiments are necessary to assess the influence of such large differences among the inventories. The emissions from biomass burning are included using the Fire Inventory from NCAR (FINN) version 1.0 (Wiedinmyer et al., 2011). The Model of Emissions of Gases and Aerosols from Nature (MEGAN) is used to include the biogenic emissions (Guenther et al., 2006) in the model.

The HTAP inventory is available at monthly temporal resolution, while INTEX-B and SEAC4RS are available as annual averages; however, seasonal variability in anthropogenic emissions may not have a major effect in this study as we focus here on spring (pre-monsoon), for which monthly emissions are similar to the annual mean (seasonal factor close to unity) (Fig. S1 in the Supplement; also see Fig. 2b in Kumar et al., 2012b). Nevertheless, seasonal influence during spring is strongest for biomass-burning emissions, which have been accounted for. The emissions from all inventories were injected in the lowest model layer. The diurnal profiles of the anthropogenic emissions of ozone precursors, specific to south Asia, are not available. A sensitivity simulation implementing the diurnal emission profile available for Europe (Mar et al., 2016 and references therein) showed a little impact on predicted noontime ozone over south Asia (Fig. S2). 
Table 2. Subregional estimates of anthropogenic emissions (in million $\mathrm{molh}^{-1}$ ) in the three emission inventories used.

\begin{tabular}{l|rrr|rrr|rrr}
\hline & \multicolumn{3}{|c|}{ HTAP } & \multicolumn{3}{c|}{ INTEX-B } & \multicolumn{3}{c}{ SEAC4RS } \\
\cline { 2 - 9 } Region & $\mathrm{NO}_{x}$ & NMVOC & $\mathrm{CO}$ & $\mathrm{NO}_{x}$ & NMVOC & $\mathrm{CO}$ & $\mathrm{NO}_{x}$ & NMVOC & $\mathrm{CO}$ \\
\hline North & 8.1 & 14.0 & 110.0 & 6.3 & 10.0 & 96.1 & 8.7 & 10.7 & 86.9 \\
East & 5.8 & 10.1 & 102.9 & 6.0 & 6.9 & 78.8 & 6.7 & 8.2 & 72.4 \\
West & 2.9 & 4.6 & 31.0 & 1.8 & 2.1 & 24.7 & 3.7 & 2.9 & 24.3 \\
Central & 4.6 & 4.2 & 44.6 & 2.0 & 2.9 & 34.7 & 4.9 & 3.1 & 26.2 \\
South & 5.4 & 5.8 & 37.2 & 2.7 & 4.1 & 46.2 & 3.5 & 3.4 & 28.3 \\
Total & 26.8 & 38.7 & 325.7 & 18.8 & 26.0 & 280.5 & 27.5 & 28.3 & 238 \\
\hline
\end{tabular}
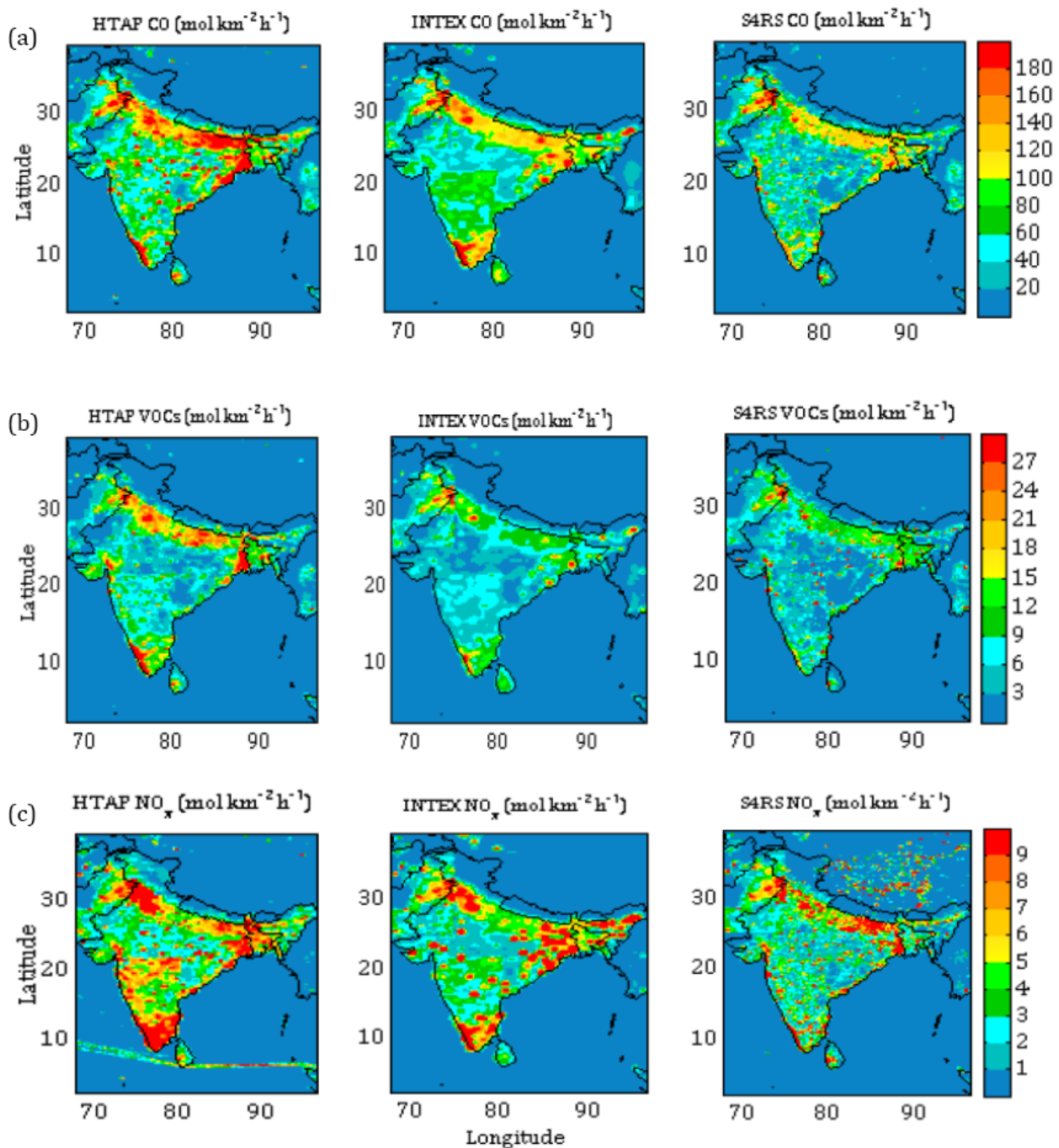

Figure 2. Comparison of (a) CO, (b) NMVOC and (c) $\mathrm{NO}_{x}$ emissions between the three inventories used (see Sect. 2.2 for description).

\subsection{Simulations}

We have conducted four different numerical simulations, as summarized in Table 3 and briefly described here. Three simulations correspond to three different emission inventories (HTAP, INTEX-B and SEAC4RS) for the anthropogenic emissions of ozone precursors, employing the RADM2 chemical mechanism. These simulations are named HTAPRADM2, INTEX-RADM2 and S4RS-RADM2, respectively. The emissions of aerosols have been kept the same (HTAP) among these three simulations and aerosol-radiation feedback has been switched off to specifically identify the effects 
of emissions of $\mathrm{O}_{3}$ precursors on modelled ozone. An additional simulation (HTAP-MOZ) has been conducted to investigate the sensitivity of ozone to the employed chemical mechanism (MOZART vs. RADM2) by keeping the emissions fixed to HTAP.

\subsection{Observational dataset}

Previous studies have shown that WRF-Chem accurately reproduces the synoptic-scale meteorology over the Indian region, justifying its use for atmospheric chemical simulations (e.g. Kumar et al., 2012a). Further, nudging towards reanalysis data limits deviations in simulated meteorology (e.g. Kumar et al., 2012a; Ojha et al., 2016; Girach et al., 2017). Nevertheless, we include an evaluation of model-simulated water vapour, temperature and wind speed against radiosonde observations (Fig. S3). Vertical profiles of the monthly average (April) water vapour mixing ratio $\left(\mathrm{g} \mathrm{Kg}^{-1}\right)$, temperature $\left({ }^{\circ} \mathrm{C}\right)$ and horizontal wind speed $\left(\mathrm{m} \mathrm{s}^{-1}\right)$ have been obtained from radiosonde data (available at $\mathrm{http}: / /$ weather.uwyo.edu/ upperair/sounding.html) for evaluation of modelled meteorology over Delhi (in north India), Bhubaneswar (in east India) and Ahmedabad (in west India). We find that modelsimulated meteorology is in good agreement (within 1 standard deviation (SD) variability) with the observations.

Surface ozone data are acquired from various studies and sources, as given in Table 4. In general, surface $\mathrm{O}_{3}$ measurements over these stations have been conducted using the well-known technique of UV light absorption by ozone molecules at about $254 \mathrm{~nm}$, making use of the Beer-Lambert law. The accuracy of these measurements is reported to be about $5 \%$ (Kleinmann et al., 1994). The response time of such instruments is about $20 \mathrm{~s}$ and instruments have a lower detection limit of 1 ppbv (Ojha et al., 2012). Here, we have used the hourly and monthly average data for the model evaluation. The details of the instrument and calibrations at individual stations can be found in the references given in Table 4. It is to be noted that most of the observations are conducted generally inside the campuses of universities/institutes, reasonably away from the direct roadside emissions/exhaust (see references provided in Table 4) and therefore not influenced by concentrated local pollution sources.

As simultaneous measurements at different stations are very sparse over south Asia, the model evaluation has often been conducted using observations of the same season/month of a different year (e.g. Kumar et al., 2012b, 2015; Ojha et al., 2016). However, to minimize the effect of temporal differences, we preferentially used measurements of recent years; i.e. the observations at the stations used in this study are for the period of 2009-2013. For four stations - Delhi (north India), Jabalpur (central India), Pune (west India) and Thumba (south India) - the observations and simulations are for the same year (2013). Finally, we investigated the effects of temporal differences on the results and model biases pre- sented here by conducting another simulation for a different year (2010) (Fig. S4).

There is also a need to evaluate precursor mixing ratios over the region to further reduce uncertainties in modelled ozone over south Asia. However, very limited data are available for ozone precursors in India and adjacent countries (especially for NMVOCs). We include an evaluation of modelled $\mathrm{NO}_{x}$, ethane and ethene mixing ratios against several recent observations in the Supplement (see Table S1). More sensitive techniques (e.g. blue light converter for $\mathrm{NO}_{2}$ ) in future would provide better insights into model performance in reproducing $\mathrm{NO}_{x}$ over India.

\section{Effects of emission inventories}

\subsection{Spatial distribution of ozone}

The spatial distribution of WRF-Chem simulated $24 \mathrm{~h}$ monthly average ozone during April is shown in Fig. 3a for the three different emission inventories (HTAP, INTEX and SEAC4RS). Generally, the months of March and May are marked with seasonal transition from winter to summer and summer to monsoon, respectively. Hence, the month of April is chosen to represent the pre-monsoon season, as it is not influenced by these seasonal transitions, and the observational data are available for a maximum number of stations during this month for the comparison. The $24 \mathrm{~h}$ average ozone mixing ratios are found to be $40-55$ ppbv over most of the Indian subcontinent for all the three inventories. Model-simulated ozone levels over the coastal regions are also similar (30-40 ppbv) among the three inventories. The highest ozone mixing ratios (55 ppbv and higher) predicted in the south Asian region are found over northern India and the Tibetan Plateau. The WRF-Chem simulated spatial distributions of average ozone shown here are in agreement with a previous evaluation study over south Asia (Kumar et al., 2012b). Further, it is found that qualitatively as well as quantitatively the HTAP, INTEX-B and SEAC4RS can lead to very similar distributions of $24 \mathrm{~h}$ average ozone over most of the south Asian region. The $24 \mathrm{~h}$ monthly average ozone from observations is superimposed on the model results in Fig. 3a for comparison. WRF-Chem simulated distributions of average $\mathrm{O}_{3}$ are in general agreement with the observational data (Fig. 3a), except at a few stations near coasts (e.g. Kannur and Thumba) and in complex terrain (Pantnagar and Dibrugarh). In contrast to the distribution of $24 \mathrm{~h}$ average $\mathrm{O}_{3}$, the noontime (11:30-16:30 IST) $\mathrm{O}_{3}$ mixing ratios over continental south Asia exhibit significant differences among the three emission inventories (Fig. 3b). HTAP clearly leads to higher noontime $\mathrm{O}_{3}$ mixing ratios, the difference being up to $10 \mathrm{ppbv}$ over the Indo-Gangetic Plain (IGP), 20 ppbv over central India and $30 \mathrm{ppbv}$ over southern India, compared to INTEX-B and SEAC4RS. The mean bias (MB) (model-observation) for $24 \mathrm{~h}$ and noontime average 
Table 3. A brief description of the different WRF-Chem simulations conducted. "Sr. no." indicates the serial number.

\begin{tabular}{lllrrl}
\hline Sr. no. & $\begin{array}{l}\text { Simulation } \\
\text { name }\end{array}$ & $\begin{array}{l}\text { Emission } \\
\text { inventory }\end{array}$ & $\begin{array}{r}\text { Year of emission } \\
\text { emission inventory }\end{array}$ & $\begin{array}{r}\text { Spatial resolution of } \\
\text { inventory }\end{array}$ & $\begin{array}{l}\text { Chemical } \\
\text { mechanism }\end{array}$ \\
\hline 1 & HTAP-RADM2 & HTAP & 2010 & $0.1^{\circ} \times 0.1^{\circ}$ & RADM2 \\
2 & INTEX-RADM2 & INTEX-B & 2006 & $0.5^{\circ} \times 0.5^{\circ}$ & RADM2 \\
3 & S4RS-RADM2 & SEAC4RS & 2012 & $0.1^{\circ} \times 0.1^{\circ}$ & RADM2 \\
4 & HTAP-MOZ & HTAP & 2010 & $0.1^{\circ} \times 0.1^{\circ}$ & MOZART-4 \\
\hline
\end{tabular}

Table 4. List of observation sites and data sources used. Site nomenclature in brackets in column 1 is used in Figs. 1, 5, 6, 9 and 10.

\begin{tabular}{|c|c|c|c|c|c|c|}
\hline Site & Type & Latitude & Longitude & $\begin{array}{l}\text { Altitude } \\
\text { (m a.s.l) }\end{array}$ & Data period & Reference \\
\hline Mohali (MOH) & Urban & $30.7^{\circ} \mathrm{N}$ & $76.7^{\circ} \mathrm{N}$ & 310 & May 2012 & Sinha et al. (2014) \\
\hline Nainital (NTL) & Highly complex & $29.37^{\circ} \mathrm{N}$ & $79.45^{\circ} \mathrm{E}$ & 1958 & Apr 2011 & Sarangi et al. (2014) \\
\hline Pantnagar (PNT) & Urban/complex & $29.0^{\circ} \mathrm{N}$ & $79.5^{\circ} \mathrm{E}$ & 231 & Apr 2009-2011 & Ojha et al. (2012) \\
\hline Delhi (DEL) & Urban & $28.65^{\circ} \mathrm{N}$ & $77.27^{\circ} \mathrm{E}$ & 220 & Apr 2013 & SAFAR data \\
\hline Dibrugarh (DBG) & Rural/complex & $27.4^{\circ} \mathrm{N}$ & $94.9^{\circ} \mathrm{E}$ & 111 & Apr 2010-2013 & Bhuyan et al. (2014) \\
\hline Kanpur (KNP) & Urban & $26.46^{\circ} \mathrm{N}$ & $80.33^{\circ} \mathrm{E}$ & 125 & Mar-May 2010-2013 & Gaur et al. (2014) \\
\hline Udaipur (UDP) & Urban & $24.58^{\circ} \mathrm{N}$ & $73.68^{\circ} \mathrm{E}$ & 598 & Apr 2010 & Yadav et al. (2014) \\
\hline Jabalpur (JBL) & Complex & $23.17^{\circ} \mathrm{N}$ & $79.92^{\circ} \mathrm{E}$ & 411 & Apr 2013 & Sarkar et al. (2015) \\
\hline Ahmedabad (ABD) & Urban & $23.03^{\circ} \mathrm{N}$ & $72.58^{\circ} \mathrm{E}$ & 53 & May 2011 & Mallik et al. (2015) \\
\hline Bhubaneswar (BBR) & Urban & $21.25^{\circ} \mathrm{N}$ & $85.25^{\circ} \mathrm{E}$ & 45 & Mar-May 2010 & Mahapatra et al. (2012) \\
\hline Pune (PUN) & Urban & $18.54^{\circ} \mathrm{N}$ & $73.81^{\circ} \mathrm{E}$ & 559 & Mar-May 2013 & SAFAR data; Beig et al. (2007) \\
\hline Anantapur (ANP) & Rural & $14.62^{\circ} \mathrm{N}$ & $77.65^{\circ} \mathrm{E}$ & 331 & Apr 2009 & Reddy et al. (2010) \\
\hline Gadanki (GDK) & Rural & $13.48^{\circ} \mathrm{N}$ & $79.18^{\circ} \mathrm{E}$ & 375 & Mar-May 2010-2011 & Renuka et al. (2014) \\
\hline Kannur (KNR) & Rural/coastal & $11.9^{\circ} \mathrm{N}$ & $75.4^{\circ} \mathrm{E}$ & 5 & Apr 2010 & Nishanth et al. (2012) \\
\hline Thumba/Trivendrum (TRI) & Urban/coastal & $8.55^{\circ} \mathrm{N}$ & $77^{\circ} \mathrm{E}$ & 3 & Apr 2009 & David et al. (2011) \\
\hline
\end{tabular}

ozone at individual stations is provided in the Supplement (Tables S2 and S3). A sensitivity simulation is conducted to reveal the influence of a different cumulus parameterization (Kain-Fritsch scheme) on our conclusions. The differences in the modelled surface ozone mixing ratios over most of the Indian domain are found to be within $\pm 5 \%$ (Fig. S5). The relatively large differences over some of the Indian region indicate that the Kain-Fritsch scheme tends to predict higher surface ozone mixing ratios relative to the base run (incorporating Grell 3-D ensemble scheme), which would only add up to biases in the original runs. Therefore, our conclusions are not affected.

The net photochemical $\mathrm{O}_{3}$ production rate $\left(\mathrm{ppbvh}^{-1}\right)$ from sunrise to noontime (06:30-12:30 IST), when most of the photochemical buildup of ozone takes place leading to its peak noontime mixing ratio, has been calculated utilizing the chemical tendencies in WRF-Chem (Barth et al., 2012; Girach et al., 2017). A comparison of monthly average $\mathrm{O}_{3}$ production rates among the three inventories is shown in Fig. 4. As seen also from the $\mathrm{O}_{3}$ mixing ratios (Fig. 3b), the HTAP emissions result in faster $\mathrm{O}_{3}$ production $\left(\sim 9 \mathrm{ppbvh}^{-1}\right)$ throughout the IGP region. The highest $\mathrm{O}_{3}$ production rates for INTEX-B and SEAC4RS inventories are simulated only in the east Indian regions including the eastern parts of the IGP. It is noted that the rate of $\mathrm{O}_{3}$ production is lower $\left(4-8 \mathrm{ppbvh}^{-1}\right)$ over most of the south-western
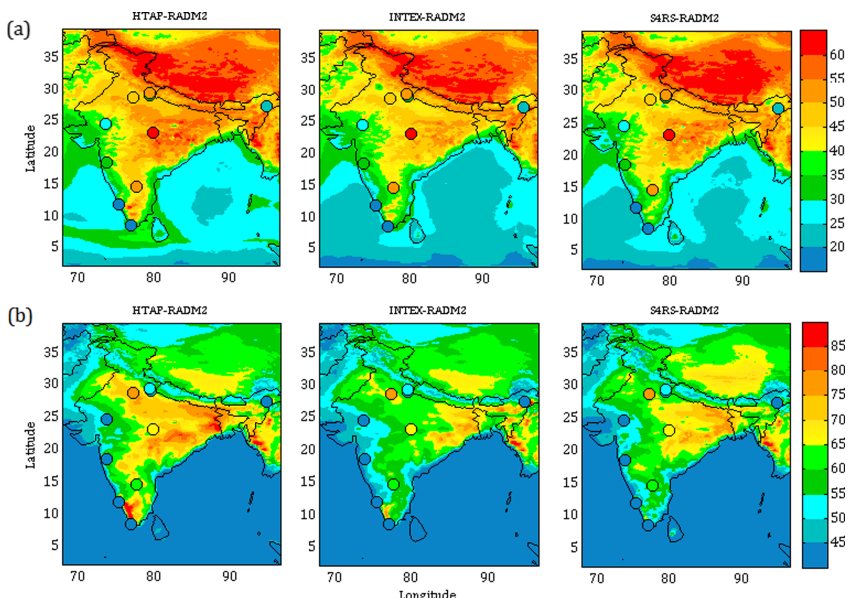

Figure 3. Monthly (April) average surface ozone calculated for (a) $24 \mathrm{~h}$ and (b) noontime (11:30-16:30 IST). The average ozone mixing ratios (ppbv) from observations are also shown for comparison on the same colour scale. Note the difference in colour scales in the top and bottom rows.

IGP for the INTEX-B and SEAC4RS inventories. Differences are also found over the southern Indian region with stronger ozone production in HTAP, followed by INTEX-B and SEAC4RS. 

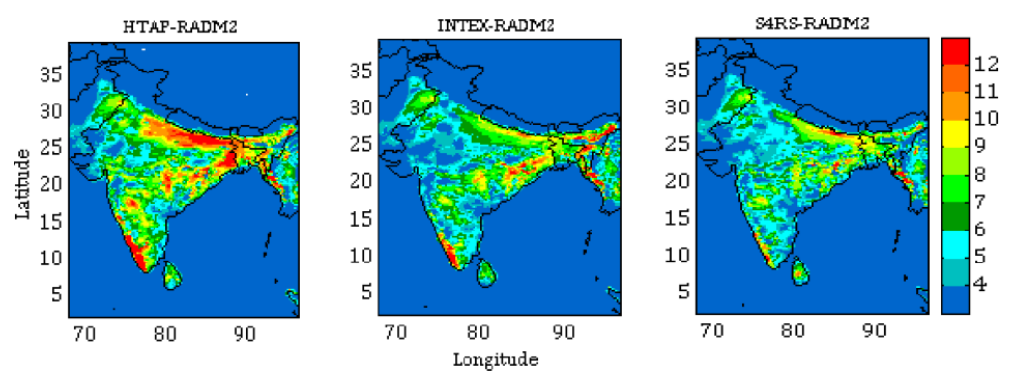

Figure 4. Net daytime surface ozone chemical tendency (in $\mathrm{ppbvh}^{-1}$ ) for the month of April during 06:30-12:30 IST.
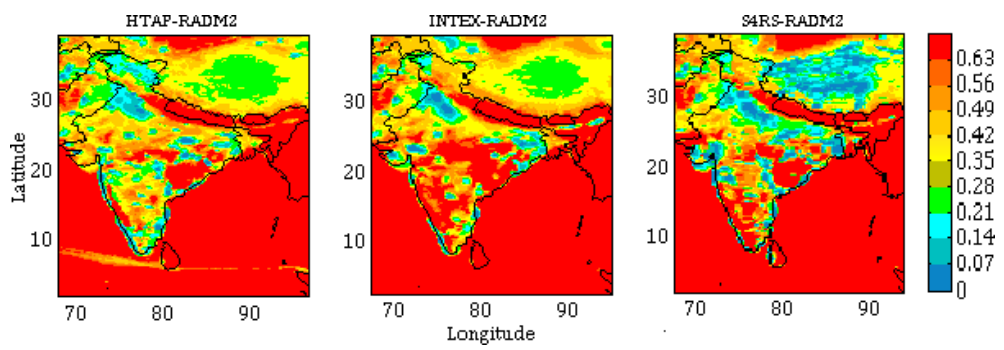

Figure 5. Net daytime surface $\mathrm{CH}_{2} \mathrm{O}$ to $\mathrm{NO}_{y}$ ratio in simulations with different inventories for the month of April during 06:30-12:30 IST.

Figure 5 provides insight into the spatial distribution of $\mathrm{O}_{3}$ production regimes estimated through the $\mathrm{CH}_{2} \mathrm{O} / \mathrm{NO}_{y}$ ratio (Geng et al., 2007; Kumar et al., 2012b), calculated during 06:30-12:30 IST, to help explain the differences in modelled ozone mixing ratios among the three simulations. The metric $\mathrm{CH}_{2} \mathrm{O} / \mathrm{NO}_{y}$, as described by Sillman (1995), is suggested to be a useful diagnostic to determine the ozone production regime. Sillman (1995) evaluated the correlation between $\mathrm{O}_{3}-\mathrm{NO}_{x}-\mathrm{VOC}$ sensitivity predicted by photochemical model and $\mathrm{CH}_{2} \mathrm{O} / \mathrm{NO}_{y}$ ratio. The correlation has been derived combining results from serial computations with the model by varying the anthropogenic and biogenic emissions, and meteorology. The method has been successfully employed in investigating ozone distribution over south Asia (Kumar et al., 2012b), east Asia (Geng et al., 2007; Tie et al., 2013) and Europe (Mar et al., 2016). Tie et al. (2013) reported similarities between the results based on the $\mathrm{CH}_{2} \mathrm{O} / \mathrm{NO}_{y}$ ratio and those following another method described by Kleinmann et al. (2003) over Shanghai. A value of 0.28 for the $\mathrm{CH}_{2} \mathrm{O} / \mathrm{NO}_{y}$ ratio is suggested to be the transitional value from the VOC-limited regime to $\mathrm{NO}_{x}$-limited regime. The spatial distribution of regimes in all simulations in the present study is largely consistent with the findings of Kumar et al. (2012b) although the latter performed the analysis for afternoon hours (11:30-14:30 IST). The S4RSRADM2 simulation predicts the entire IGP to be VOC sensitive, whereas in the HTAP-RADM2 and INTEX-RADM2 simulations, though the north-west IGP and eastern IGP are VOC sensitive, the central IGP is mostly $\mathrm{NO}_{x}$ limited. The coastal regions are also predicted to be VOC limited in all the three simulations. With the north-western IGP being VOC limited in all simulations, the noontime ozone mixing ratios are found to be higher in this region in the HTAP-RADM2 simulation because of high NMVOC emissions in the HTAP inventory as evident from Fig. 2 and Table 2. Similar differences are also apparent in southern India.

Some of the ozone precursors $\left(\mathrm{NO}_{x} / \mathrm{NO}_{y}\right.$, ethane and ethene) are also compared between the model and recent measurements over few stations (Table S1). Significant differences are seen in model-simulated $\mathrm{NO}_{x}$ mixing ratios among different emission inventories (e.g. 6.5-30.5 ppbv at Kanpur) over the urban stations in the IGP. The model typically overestimated $\mathrm{NO}_{x}$ mixing ratios at Delhi except in the INTEX-RADM2 simulation, which showed an agreement with observations within $1 \mathrm{SD}$. Total nitrogen oxides $\left(\mathrm{NO}_{y}\right)$ showed relatively similar levels among different inventories (2.7-3.2 ppbv) at a high-altitude station (Nainital) in north India and were only slightly higher than the observed mean $(1.8 \pm 1.6 \mathrm{ppbv})$. In contrast with the stations in northern India, $\mathrm{NO}_{x}$ levels over a rural station (Udaipur) in western India are underestimated by a factor of 4 . On the other hand, modelled ethane mixing ratios are underpredicted by a factor of about 2, whereas modelled ethene mixing ratios agree relatively well with observed values at Nainital in INTEX-RADM2 and S4RS-RADM2 as compared to HTAPRADM2. More in situ observations, especially of ozone precursors, may provide better insights into the performance of the numerical models and employed emission inventories over this region.

In summary, these results show similar $24 \mathrm{~h}$ average ozone distributions but large differences in the ozone buildup until noon. The net photochemical ozone production in the 
morning hours (06:30-12:30 IST) is shown to be sensitive to the different inventories over this region, which is attributed to differences in total $\mathrm{NO}_{x}$ and/or NMVOC emissions. We therefore suggest that a focus on $24 \mathrm{~h}$ averages only would be insufficient to evaluate the ozone budget and implications for human health and crop yield. Next, we compare the modelled diurnal ozone variations from three inventories with in situ measurements over 15 stations across south Asia.

\subsection{Diurnal variation}

A comparison of WRF-Chem simulated diurnal ozone variability with recent in situ measurements over a network of 15 stations in the south Asian region is shown in Fig. 6. WRF-Chem is found to successfully reproduce the characteristic diurnal ozone patterns observed over the urban (e.g. Mohali, Delhi, Kanpur, Ahmedabad, Bhubaneswar and Pune) and rural (e.g. Anantapur, Gadanki) stations, indicating strong ozone buildup from sunrise to noontime and the predominance of chemical titration (by NO) and deposition losses during the night. In general, WRF-Chem captures the daily amplitude of $\mathrm{O}_{3}$ changes at relatively cleaner and highaltitude stations, typically showing less pronounced diurnal variability, such as Nainital in the Himalayas, although with differences in timing when the model and observations attain minimum ozone mixing ratios, thus leading to relatively low correlation coefficients (see later in the text). The diurnal variability in $\mathrm{O}_{3}$ indicated by $\Delta \mathrm{O}_{3}$, i.e. the difference between diurnal mean and hourly values, is further compared between the model and observations at all the stations (Fig. S6). This comparison intends to focus more on evaluating the model's ability to reproduce different diurnal patterns over urban, rural and clean chemical environments and minimizing the representation of absolute ozone levels. It is seen that model successfully captures the observed variability in ozone at most of the sites in this region. However, a limitation is noticed in resolving the stations well in the vicinity of complex terrain (such as in Jabalpur), attributed to the stronger spatial heterogeneity due to forests, hills and mountains within a small area (Sarkar et al., 2015).

To briefly evaluate the possible effects due to the difference in meteorological year between the model and observations, we repeated the HTAP-RADM2 simulation for a different year (2010) as shown in the Supplement (Fig. S4). The effect of changing the meteorological year in the model simulation is generally small (mostly within \pm 3 ppbv in 3 years), except at a few stations in the north (Nainital and Pantnagar) and east (Bhubaneswar). The effect is seen to vary from 4.8 to $6 \mathrm{ppbv}$ (in 3 years) at these three stations. These differences are found to be associated with the interannual variations in the regional and transported biomassburning emissions, as seen from MODIS fire counts and MOZART/GEOS5 boundary conditions (not shown here).

The model ability to reproduce diurnal variations at all stations is summarized using a Taylor diagram (Taylor, 2001) in Fig. 7. The statistics presented are normalized SD, normalized centred root mean square difference (RMSD) and the correlation coefficient. The normalization of both SD and RMSD is done using the SD of the respective observational data. The point indicated as "REF" represents the observational data against which the model results are evaluated. WRF-Chem simulations show reasonable agreement with observations showing correlation coefficients generally greater than 0.7 for most sites. The locations such as Nainital and Jabalpur for which $r$ values are lower (0.3-0.7) are associated with unresolved complex terrain, as mentioned earlier. Note that the Taylor diagram has been used to present evaluation statistics for a general overview and intercomparison, i.e. how the model reproduces the diurnal variation at different stations, irrespective of the emission inventory.

\section{Effects of chemical mechanism (RADM2 vs. MOZART)}

Choice of chemical mechanisms in the regional models can also be an important element in the prediction of ozone. Inclusion of additional chemical species along with insufficient information on region-specific speciation factors could induce uncertainties to the predicted ozone. Further, in order to reduce the computational costs most chemical mechanisms in the models make use of the lumping approach to reduce the number of chemical reactions, thus avoiding treatment of all chemical species (Zaveri et al., 1999; Sarkar et al., 2016). In addition, different reaction rate constants, photolysis and dry deposition schemes used in the mechanisms are some of the factors leading to the uncertainties. A recent WRFChem evaluation over Europe showed better agreement with in situ measurements when the MOZART chemical mechanism was employed, compared to RADM2 (Mar et al., 2016). Following up on this, here we compare modelled ozone mixing ratios obtained with these two extensively used chemical mechanisms over south Asia: RADM2 (e.g. Michael et al., 2013; Ojha et al., 2016; Girach et al., 2017) and MOZART (e.g. Ghude et al., 2014, 2016), by keeping the same input emission inventory (HTAP). In the present study, the photolysis rates are calculated using the Fast-J photolysis scheme (Wild et al., 2000) in RADM2 simulations and the Madronich FTUV scheme in the MOZART simulation. In WRF-Chem, the Madronich FTUV photolysis scheme uses climatological $\mathrm{O}_{3}$ and $\mathrm{O}_{2}$ overhead columns. The treatment of dry deposition process also differs between RADM2 and MOZART due to differences in Henry's law coefficients and diffusion coefficients. Thus, the following sensitivity analysis is aimed at exploring if the use of the more detailed chemical mechanism of MOZART could improve the model performance. 

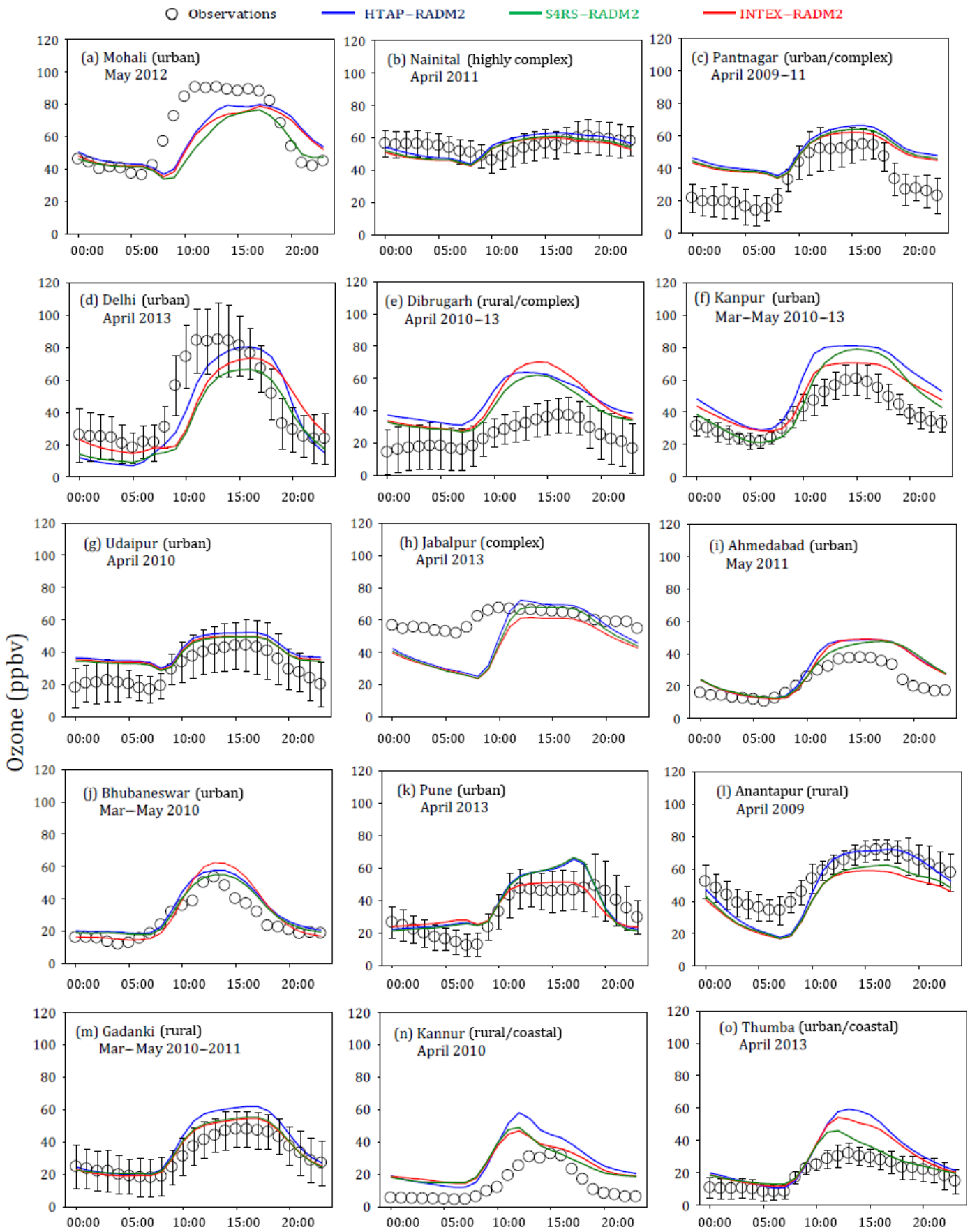

Time (IST)

Figure 6. Comparison of monthly average diurnal variation of surface ozone simulated using different emission inventories at various observation sites. The observational data are available for the period indicated in the figure, whereas all model simulations are for the year 2013. Error bars represent the temporal standard deviations (SDs) of the monthly averages. All model simulations are with RADM2 chemistry.

\subsection{Spatial distribution of surface $\mathrm{O}_{3}$}

The WRF-Chem simulated spatial distributions of $24 \mathrm{~h}$ average and noontime average surface ozone are compared in
Fig. 8 . The monthly values of the $24 \mathrm{~h}$ and noontime ozone mixing ratios from measurements are also shown. Overall, the average ozone mixing ratios over south Asia are simulated to be higher with the MOZART chemical mecha- 


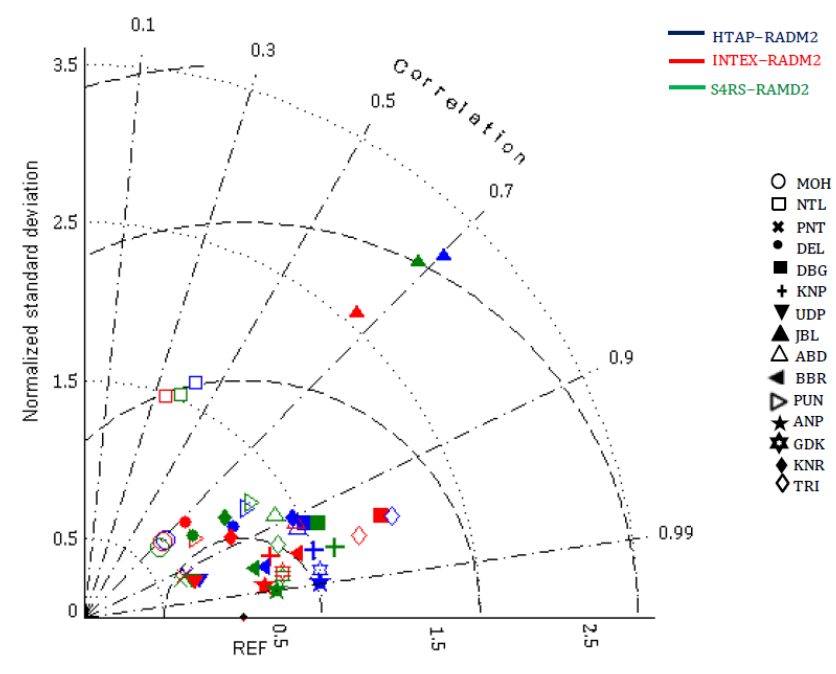

Figure 7. Taylor diagram with summary model statistics ( $r$, normalized SD and RMSD) at all sites. The correlation is the cosine of the angle from the horizontal axis, the root mean square difference is the distance from the reference point (REF) and the SD is the distance from the origin.

nism compared to RADM2, which is consistent with the results of Mar et al. (2016) for the European domain. The $24 \mathrm{~h}$ average ozone mixing ratios over India simulated with MOZART chemistry are found to be higher than those with RADM2 chemistry, especially over the eastern Indian region $(\sim 60 \mathrm{ppbv}$ and more for MOZART compared to $\sim 40$ $55 \mathrm{ppbv}$ for RADM2). Average ozone levels over the coastal regions are found to be similar between the two mechanisms (30-40 ppbv). MOZART chemistry also predicts high $24 \mathrm{~h}$ average ozone mixing ratios (55 ppbv and higher) over the Tibetan Plateau region, similar to RADM2. A striking difference between the two chemical mechanisms is found over the marine regions adjacent to south Asia (Bay of Bengal and northern Indian Ocean), with MOZART predicting significantly higher $24 \mathrm{~h}$ average ozone levels (35-50 ppbv) compared to RADM2 (25-40 ppbv). A comparison of noontime average ozone distributions between the two chemical mechanisms shows that MOZART predicts higher ozone concentrations than RADM2 over most of the Indian region by about 5-20 ppbv, except over western India. The differences are up to $20 \mathrm{ppbv}$ and more over the southern Indian region, highlighting the impacts of chemical mechanisms on modelled ozone in this region. The mean bias (MB) values (model-observation) for $24 \mathrm{~h}$ and noontime average ozone at individual stations is provided in the Supplement (Tables S2 and S3).

Figure 9a shows a comparison of the monthly average chemical $\mathrm{O}_{3}$ tendency $\left(\mathrm{ppbvh}^{-1}\right.$ ) from 06:30 to 12:30 IST. In contrast with average $\mathrm{O}_{3}$ mixing ratios, which were found to be higher in HTAP-MOZ, the net $\mathrm{O}_{3}$ production rates at the surface are higher in HTAP-RADM2 over most of the do- main, especially in the IGP and central India. The net $\mathrm{O}_{3}$ production rates at the surface with HTAP-RADM2 are found to be 6 to $9 \mathrm{ppbvh}^{-1}$ and more over the IGP, whereas these values are generally lower in HTAP-MOZ $\left(4-8 \mathrm{ppbvh}^{-1}\right)$, except in the north-eastern IGP $\left(>9 \mathrm{ppbvh}^{-1}\right)$. Figure $9 \mathrm{~b}$ shows the sum of the chemical tendency and vertical mixing tendency at the surface for the HTAP-RADM2 and HTAPMOZ. Analysis of the vertical mixing tendency revealed that higher surface ozone mixing ratios in the MOZART simulation are due to mixing with ozone-rich air from aloft. In the HTAP-RADM2 simulation, vertical mixing dilutes the effect of strong chemical surface ozone production. Further analysis of vertical distributions of chemical $\mathrm{O}_{3}$ tendencies reveals stronger photochemical production of ozone aloft with MOZART compared to RADM2 (Fig. S7). This leads to higher ozone mixing ratios aloft in MOZART simulations. A sensitivity simulation is conducted using a different PBL parameterization (Yonsei University scheme) to examine its influence on our conclusions. Comparison of monthly average (in April) planetary boundary layer heights between the two PBL schemes revealed that the differences are mostly within $\pm 150 \mathrm{~m}$ with Yonsei scheme generally resulting in higher PBL heights over India (Fig. S9). Nevertheless, the chemical tendencies combined with vertical mixing tendencies of surface $\mathrm{O}_{3}$ are found to be nearly similar with Yonsei scheme (Fig. S10) as in the base runs using the MYJ scheme (Fig. 9b) with MOZART still producing higher ozone aloft (not shown) as in the original runs. Thus, changing the PBL scheme still results in production of more ozone aloft in MOZART, which is getting mixed with near surface air, which corroborates that our conclusions are not affected.

Mar et al. (2016) showed that RADM2 exhibits greater VOC sensitivity than MOZART (i.e. producing higher changes in ozone given a perturbation in VOC emissions) under noontime summer conditions over Europe. This is consistent with our findings as well, that the net surface photochemical ozone production is greater for HTAP-RADM2 than for HTAP-MOZART, given the high VOC emissions in the HTAP inventory. At the surface, the MOZART mechanism predicts larger areas of VOC-sensitivity (as diagnosed by the $\mathrm{CH}_{2} \mathrm{O} / \mathrm{NO}_{y}$ indicator, Fig. 10) and lower net photochemical ozone production than RADM2. With increasing altitude, both the HTAP-RADM2 and HTAP-MOZART simulations show a general increase of $\mathrm{CH}_{2} \mathrm{O} / \mathrm{NO}_{y}$ over India; i.e. the chemistry tends to exhibit increased $\mathrm{NO}_{x}$ sensitivity with increasing height (Fig. S11). At model levels above the surface, HTAP-MOZART shows greater net photochemical production of ozone than HTAP-RADM2 (Fig. S7), which is what Mar et al. (2016) have also reported for the surface $\mathrm{O}_{3}$ over Europe. When these effects are combined, mixing leads to higher surface ozone mixing ratios for HTAPMOZART than for HTAP-RADM2. A sensitivity simulation using a different photolysis scheme (Madronich TUV photolysis scheme) with HTAP-RADM2 setup revealed similar surface ozone mixing ratios and chemical tendencies at various 

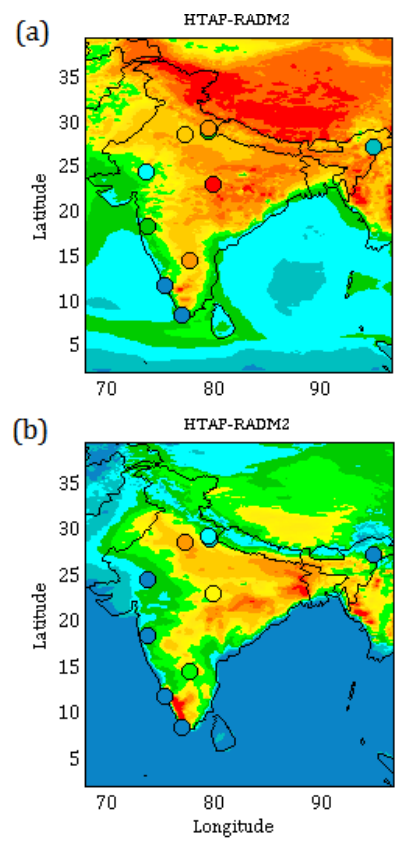
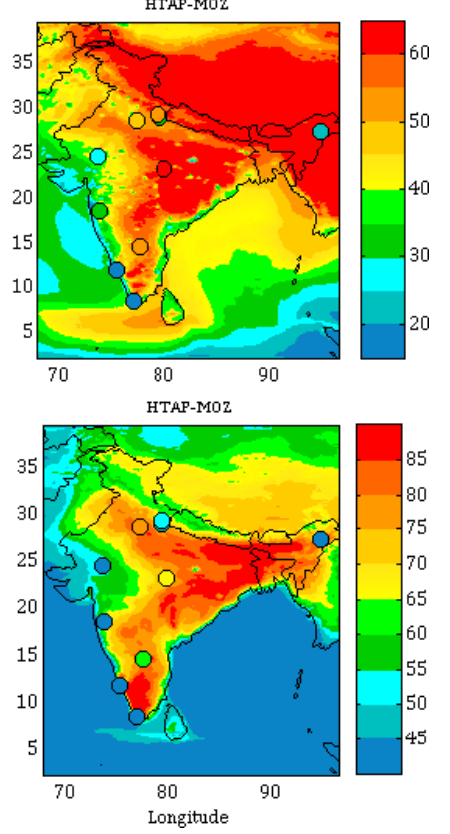

Figure 8. Monthly (April) average surface ozone calculated for (a) $24 \mathrm{~h}$ and (b) noontime (11:30-16:30 IST), comparing the chemical mechanisms (RADM2 and MOZART). The average ozone mixing ratios (ppbv) from observations are also shown for comparison on the same colour scale. Note the difference in colour scales in the top and bottom rows.
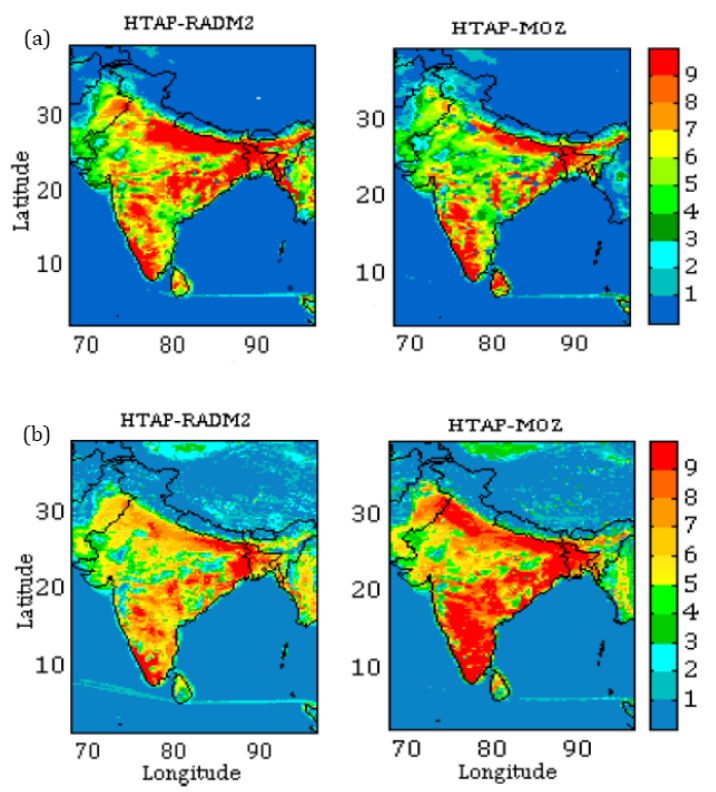

Figure 9. Average (a) net daytime surface ozone chemical tendency (in $\mathrm{ppbvh}^{-1}$ ) (b) net daytime surface ozone chemical + vertical mixing tendency (in $\mathrm{ppbvh}^{-1}$ ) for April during 06:30-12:30 IST

model levels with small differences $(<5 \%)$ over most of the Indian region (not shown). So our results would be similar if we use Madronich TUV scheme instead of Fast-J scheme
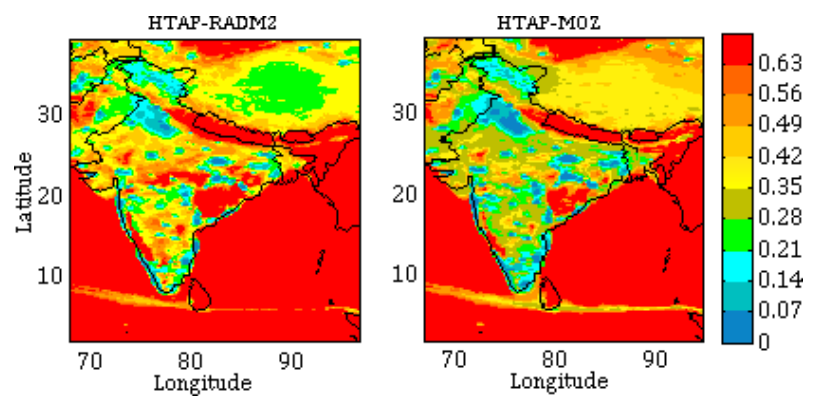

Figure 10. Net daytime surface $\mathrm{CH}_{2} \mathrm{O}$ to $\mathrm{NO}_{y}$ ratio in simulations with different chemical mechanisms for the month of April during 06:30-12:30 IST.

with RADM2. Further, Mar et al. (2016) used Madronich TUV scheme with RADM2 and Madronich F-TUV scheme with MOZART chemical mechanism and reported that the two different Madronich photolysis schemes had only a small contribution to the differences in the predicted ozone by two chemical mechanisms. The major difference between the two chemical mechanisms was due to differences in inorganic reaction rates (Mar et al., 2016). Hence, we conclude that in our study too, the differences over Indian region are primarily due to the choice of the chemical mechanisms irrespective of photolysis scheme used. Also note that the aerosol radiation feedback is turned off, so that the calculated differences mainly result from the representation of gas-phase chemistry rather than of aerosols between MOZART and RADM2. Our analysis also shows the importance of chemical regime in understanding differences between the chemical mechanisms and highlights the significant effects of the employed chemical mechanism on modelled ozone over south Asia.

\subsection{Diurnal variation}

Figure 11 shows a comparison of WRF-Chem simulated ozone variations on diurnal timescales with recent in situ measurements over a network of stations across south Asia for the two chemical mechanisms (MOZART and RADM2); again with the same emission inventory (HTAP). Qualitatively, both simulations produce very similar diurnal patterns (see also Fig. S12); however, the absolute $\mathrm{O}_{3}$ mixing ratios are found to differ significantly (Fig. 11) between the two chemical mechanisms. Noontime ozone mixing ratios predicted by MOZART are either significantly higher (at 9 out of 15 stations) or nearly similar (at 6 stations). MOZARTpredicted $\mathrm{O}_{3}$ at Dibrugarh, Kanpur, Jabalpur, Bhubaneswar, Gadanki and Thumba was found to be higher by $\sim 12 \mathrm{ppbv}$, 5, 8 ppbv, 10, 11 and $12 \mathrm{ppbv}$, respectively, compared to RADM2 (Table S3). Over several urban and rural stations in India (e.g. Delhi, Ahmedabad, Pune, Kannur and Thumba) MOZART is found to titrate ozone more strongly during the night while resulting in higher or similar ozone levels around noon. The contrasting comparison between noon and night- 
time found at these sites suggests that evaluation limited to $24 \mathrm{~h}$ averages would not be sufficient and that model performance on a diurnal timescale should be considered to assess the photochemical buildup of $\mathrm{O}_{3}$.

The model performance of two chemical mechanisms in reproducing diurnal variation at all stations is summarized using a Taylor diagram in Fig. 12. Both chemical mechanisms show reasonably good agreement $(r>0.7)$ at most of the sites, except one station associated with highly complex terrain (Nainital). On the Taylor diagram, most of the HTAPRADM2 results are found to be closer to the "REF", as compared to HTAP-MOZ results, suggesting that the RADM2 chemical mechanism is better suited to simulate diurnal variation of ozone over this region.

\section{Overall evaluation}

In this section, we present a subregional evaluation of all simulations by subdividing the domain into five geographical areas, i.e. north, south, east, west and central India, as shown in Fig. 1. The temporal correlation coefficients of diurnally varying $\mathrm{O}_{3}$, spatially averaged over each of the five different subregions, are found to be reasonably high, generally exceeding 0.7 (Table 5). The $r$ values for individual subregions are found to be similar among the four simulations. For example, over north India, the $r$ values vary from 0.86 to 0.90 . The model performance differs among several subregions, with correlations being lower for central India $(r=0.67-0.75)$. Since the latter is based on only one station associated with complex terrain (Jabalpur), we suggest that observations over additional stations should be conducted to evaluate the model performance in the central Indian region. The mean bias values around noontime are provided in the Supplement (Table S5). These results show that the performance of emission inventories is regionally different and that these biases should be considered in utilizing model for assessment of air quality and impacts on human health and crop yield.

We finally evaluate the different simulations in the context of the entire south Asian region. Figure 13 shows a comparison of model results and measurements with diurnal boxand-whisker plots, combining all stations for the four different simulations. It is clearly seen that HTAP-MOZ yields the highest noontime surface ozone mixing ratios among all simulations, followed by HTAP-RADM2. These results further suggest that assessment of the tropospheric ozone budget as well as implications for public health and crop loss are associated with considerable uncertainty, and biases need to be considered. A recent study (Ghude et al., 2016) utilizing MOZART chemistry, for example, subtracted 15 ppbv from the WRF-Chem simulated ozone mixing ratios before deriving premature mortalities over the Indian region. The results of the present study are summarized in the form of a polar plot (Fig. 14) showing the monthly mean diurnal variation from all runs for the entire south Asian domain. The noontime normalized mean bias values with respect to observed values are $\sim 9.7 \%$ (S4RSRADM2), $\sim 11.5 \%$ (INTEX-RADM2), $\sim 20.9 \%$ (HTAPRADM2) and $\sim 34.2 \%$ (HTAP-MOZ). It is to be noted that comparison of absolute ozone levels from the model with observations has a limitation due to non-consideration of aerosol impacts and the resolution at which the model results are obtained; nevertheless, it provides an estimate of the uncertainties in model predictions of ozone using different emission inventories. It is interesting to note that the SEAC4RS inventory (representative of the year 2012) yields quite a similar domain-wide average bias value to the INTEX-B inventory (representative of the year 2006).

\section{Summary and conclusions}

In this paper, we compare the WRF-Chem simulated surface ozone over south Asia during the pre-monsoon season by employing three different inventories (EDGAR-HTAP, INTEX$\mathrm{B}$ and SEAC4RS) for anthropogenic emissions with the RADM2 chemical mechanism. WRF-Chem simulated ozone distributions showed highest ozone mixing ratios $(\sim 55 \mathrm{ppbv}$ and higher) over northern India and the Tibetan Plateau. In general, modelled average ozone distributions from different inventories are found to be in agreement with previous studies over this region. Evaluation on diurnal timescales demonstrates the ability of the model to reproduce observed $\mathrm{O}_{3}$ patterns at urban and rural stations, showing strong noontime ozone buildup, and chemical titration and deposition loss during the nighttime. WRF-Chem also captures the smaller diurnal amplitudes observed over high-altitude, relatively pristine stations. However, the model showed limitations in capturing ozone mixing ratios in the vicinity of the complex terrain, indicating that even a relatively high horizontal resolution of $12 \mathrm{~km} \times 12 \mathrm{~km}$ could not fully resolve the topography-induced effects.

Overall, WRF-Chem simulations show reasonable agreement with observations, with correlation coefficients generally higher than 0.7 for most of the sites. It is found that the HTAP, INTEX-B and SEAC4RS inventories can lead to very similar distributions of $24 \mathrm{~h}$ average ozone over this region. This is corroborated by the quantitative similarity in simulated surface ozone among the three simulations for both $24 \mathrm{~h}$ and noontime (11:30-16:30 IST) averages at all grids in the domain (Table S6). However, noontime (11:30-16:30 IST) $\mathrm{O}_{3}$ mixing ratios over continental south Asia differ significantly among the three inventories. This can also be seen in the quantitative assessment of similarity (Table S6), where the variance of the residual shows that the scatter is greater for the noontime averages than for the $24 \mathrm{~h}$ averages. HTAP inventory generally leads to noontime $\mathrm{O}_{3}$ mixing ratios higher by $10 \mathrm{ppbv}$ over the IGP, 20 ppbv over central India and 30 ppbv over southern India, compared to the INTEX-B 

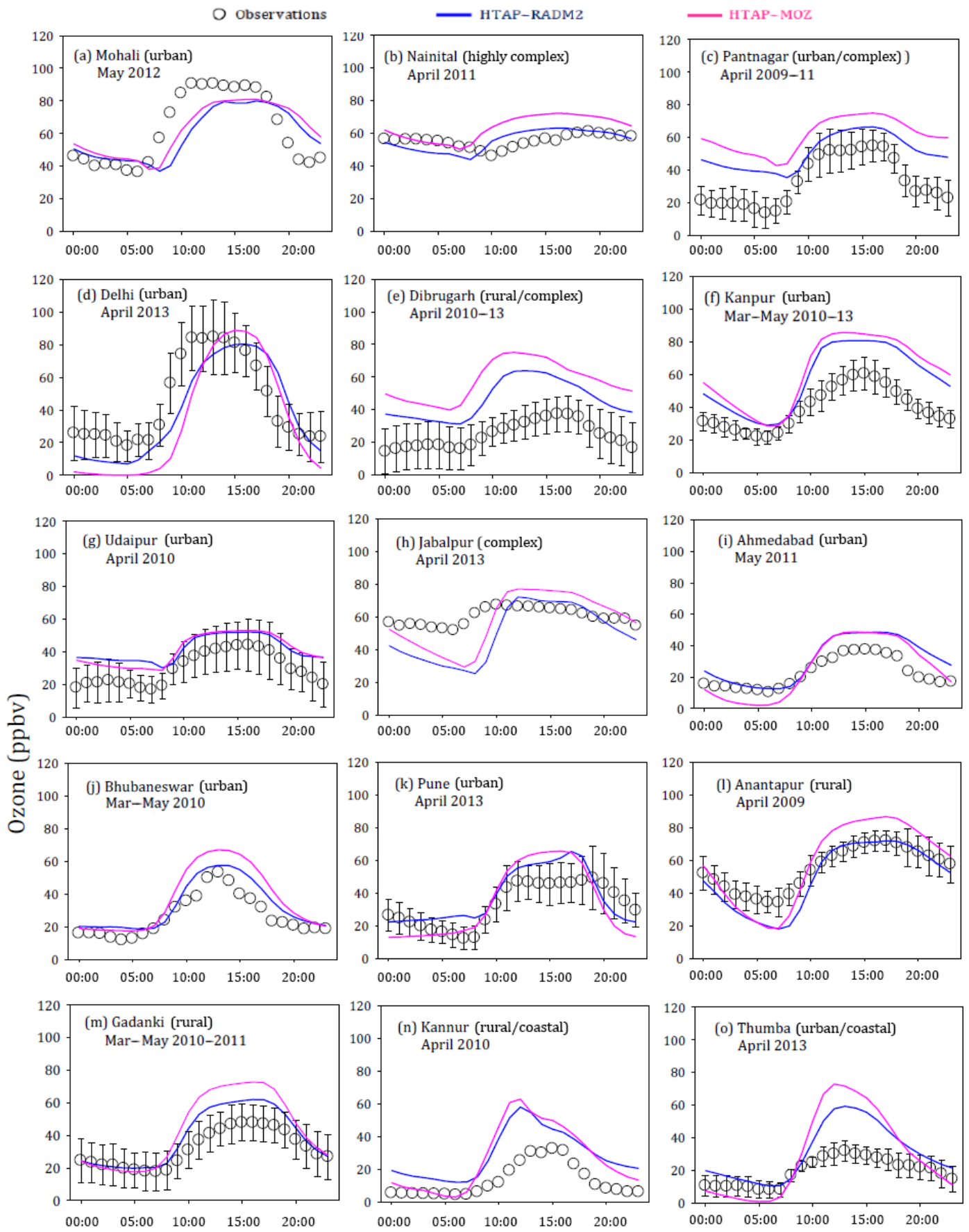

Time (IST)

Figure 11. Comparison of monthly average diurnal variation of surface ozone simulated using different chemical mechanisms at various observation sites. The observational data are available for the period indicated in the figure, whereas all the model simulations are for the year 2013. Error bars represent the temporal SDs of the monthly averages. All model simulations are with the HTAP inventory.

and SEAC4RS inventories. A comparison of the monthly average $\mathrm{O}_{3}$ net production rate during 06:30-12:30 IST among the three inventories shows that the HTAP emissions result in faster $\mathrm{O}_{3}$ production $\left(\sim 9 \mathrm{ppbvh}^{-1}\right)$ throughout the IGP region compared to the other two inventories. Differ- ences are also found over the southern Indian region with stronger ozone production in HTAP, followed by INTEX$\mathrm{B}$ and SEAC4RS. The results show similar $24 \mathrm{~h}$ average ozone distributions but large differences in noontime ozone 
Table 5. A comparison of correlation coefficients $(r)$ over different regions for the four simulations.

\begin{tabular}{lllll}
\hline Region & HTAP-RADM2 & INTEX-RADM2 & S4RS-RADM2 & HTAP-MOZ \\
\hline North & 0.90 & 0.86 & 0.88 & 0.90 \\
East & 0.98 & 0.97 & 0.97 & 0.98 \\
West & 0.99 & 0.98 & 0.98 & 0.99 \\
Central & 0.70 & 0.67 & 0.69 & 0.75 \\
South & 0.99 & 0.98 & 0.97 & 0.97 \\
Overall & 0.98 & 0.97 & 0.97 & 0.99 \\
\hline
\end{tabular}

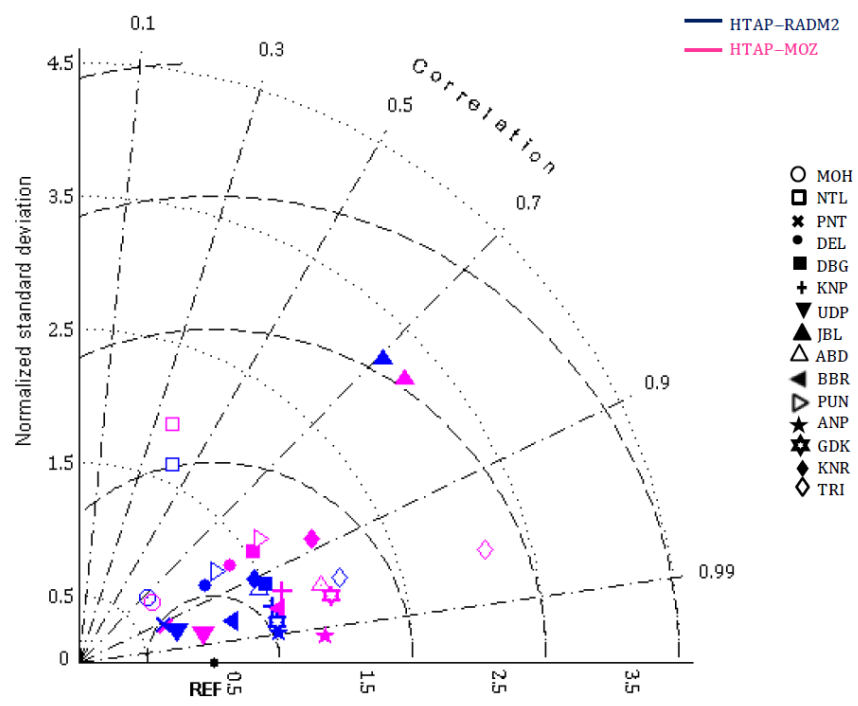

Figure 12. Taylor diagram with summary model statistics ( $r$, normalized SD and RMSD) at all sites. The correlation is the cosine of the angle from the horizontal axis, the root mean square difference is the distance from the reference point (REF) and the SD is the distance from the origin.

buildup, pointing to the uncertainties in emission inventories over this region.

We further investigated the sensitivity of modelled ozone to two extensively used chemical mechanisms, RADM2 and MOZART, by maintaining the HTAP emissions. Noontime average surface ozone distributions predicted by MOZART show significant enhancements (10-15 ppbv) with respect to RADM2 over most of the Indian region, except over western India. MOZART predicts higher ozone concentrations than RADM 2 by up to $20 \mathrm{ppbv}$ and more over the south Indian region. Monthly average ozone mixing ratios are predicted to be higher by the MOZART chemical mechanism compared to RADM2, as was also found over Europe (Mar et al., 2016). The differences in ozone production between the MOZART and RADM2 chemical mechanisms are mainly attributed to the additional chemical species and reactions, differences in the rate constants for several inorganic reactions and photolysis schemes used. The difference in photolysis rates for $\mathrm{O}^{1} \mathrm{D}$ and $\mathrm{NO}_{2}$ can be seen in the Supplement (Fig. S13) for a surface point in the centre of the domain. A comparison of the monthly average chemical $\mathrm{O}_{3}$ tendency $\left(\mathrm{ppbvh}^{-1}\right)$ during 06:30-12:30 IST shows that in contrast with average $\mathrm{O}_{3}$ mixing ratios, which were found to be higher in MOZART, the net $\mathrm{O}_{3}$ production rates at the surface are higher with RADM2 chemistry, especially over the IGP and central India. The net $\mathrm{O}_{3}$ production rates at the surface with RADM2 are found to be 6 to $9 \mathrm{ppbvh}^{-1}$, and higher over the IGP, whereas these rates are generally lower with MOZART (4$\left.8 \mathrm{ppbvh}^{-1}\right)$, except in the north-eastern IGP $\left(>9 \mathrm{ppbvh}^{-1}\right)$. Analysis of the vertical mixing tendency revealed that higher surface ozone mixing ratios in the MOZART simulation are due to mixing with ozone-rich air from aloft. Analysis of vertical distributions of chemical $\mathrm{O}_{3}$ tendencies reveals stronger photochemical production of ozone aloft with MOZART compared to RADM2. Our analysis highlights the significant effects of the employed chemical mechanism on model predicted ozone over south Asia.

Qualitatively, RADM2 and MOZART simulations predict similar diurnal patterns. However, over several urban and rural stations in India, MOZART is found to titrate ozone relatively well during the night, while producing higher or similar ozone levels during noontime compared to RADM2. The contrasting evaluation results between daytime (noon) and nighttime could counterbalance in evaluation studies limited to $24 \mathrm{~h}$ averages, possibly showing better agreement, and therefore it is pertinent to consider the diurnally resolved model performance.

Model results averaged over all observation sites encompassing the south Asian region revealed that HTAP-MOZ predicts highest noontime ozone mixing ratios followed by HTAP-RADM2. The noontime normalized mean bias compared to observations is lowest for the SEAC4RS inventory with the RADM2 chemical mechanism $(\sim 9.7 \%)$, followed by INTEX-B with RADM2 $(\sim 11.5 \%)$, HTAP with RADM2 $(\sim 20.9 \%)$ and HTAP with MOZART $(\sim 34.2 \%)$. These results further suggest that the assessment of the tropospheric ozone budget and consequently its implications on public health and agricultural output should be carried out cautiously by considering the large uncertainties associated with use of emission inventories and chemical mechanism incorporated. As we report considerable differences in the noontime ozone levels among different inventories, further 

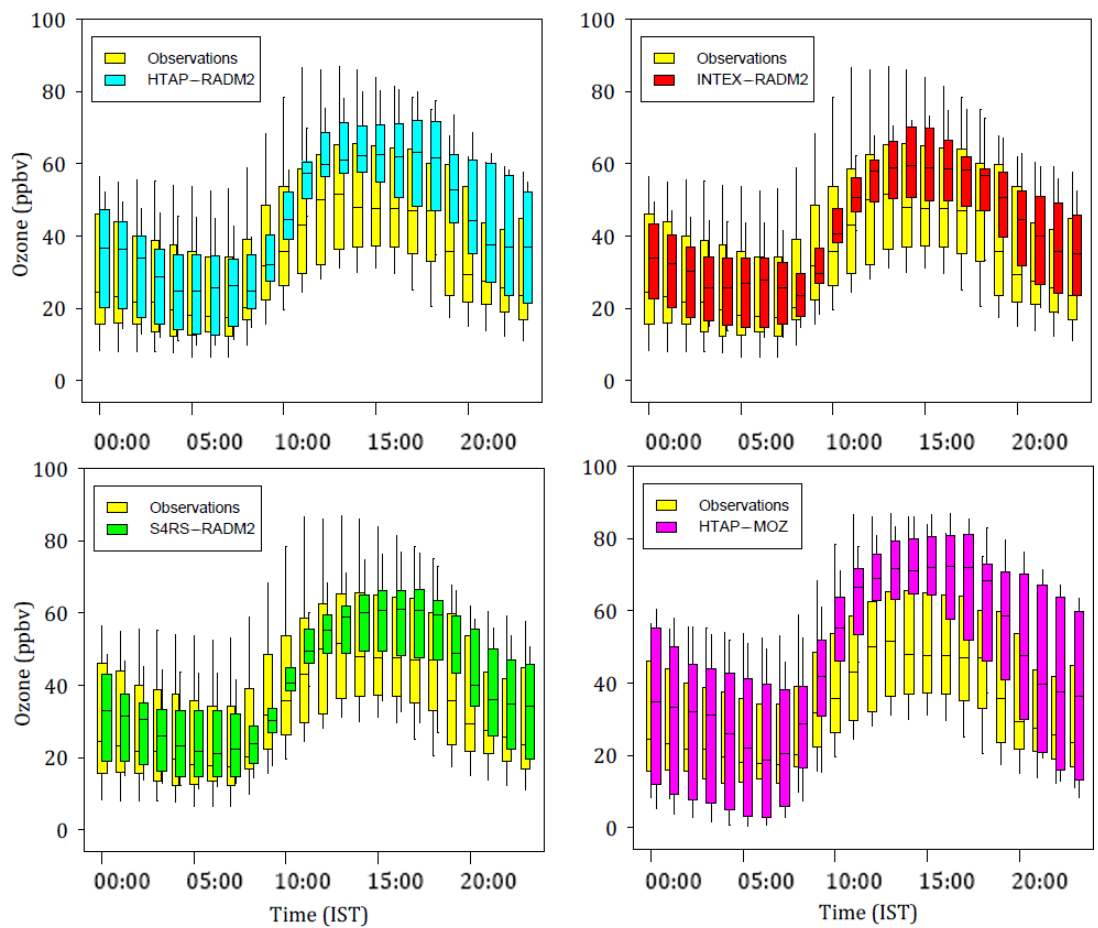

Figure 13. Box-and-whisker plot comparison of the monthly average diurnal variation of surface ozone from model runs and observations over the entire domain (after spatially averaging the results). Upper and lower boundaries of boxes denote the 75 th and 25 th percentiles, and whiskers represent the 95 th and 5 th percentiles. The line in the box is the median.

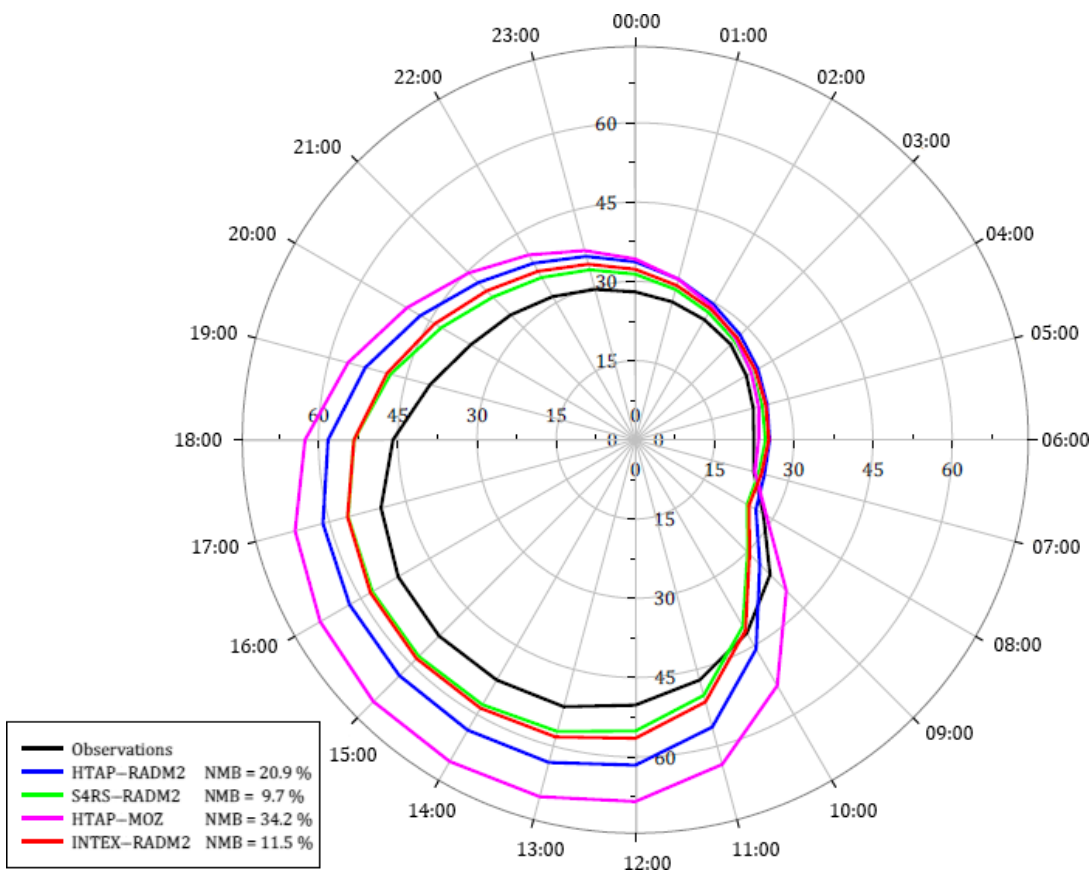

Figure 14. Polar plot for monthly mean diurnal variation of surface ozone (in ppbv) from all model simulations and observations, each spatially averaged over all sites. The numbers on the outermost circle represent the hour of the day, and the radial distance from the centre represents surface ozone mixing ratios in ppbv. The normalized mean biases (NMBs in \%) for noontime surface ozone are indicated in the caption box. 
work is needed to account for aerosol feedback and evaluation of ozone precursors to identify best-suited emission inventory for this region. Modelled levels of ozone precursors showed significant differences among simulations employing the three emission inventories, with an overestimation of $\mathrm{NO}_{x}$ levels at urban stations in the IGP. Evaluation of model-simulated levels of ozone precursors over a network of observations is highly desirable, as conducted for ozone in this study. It is interesting to note that the SEAC4RS inventory (representative of 2012) yields results comparable to the INTEX-B inventory (for 2006), even though the SECA4RS inventory has about $46 \%$ higher $\mathrm{NO}_{x}, 9 \%$ higher NMVOC and $15 \%$ lower $\mathrm{CO}$ emissions compared to INTEX-B.

Brown carbon aerosol can effectively absorb solar radiation (Alexander et al., 2008; Hecobian et al., 2010; Kirchstetter and Thatcher, 2012; Kirchstetter et al., 2004; Yang et al., 2009; Jo et al., 2016), leading to a reduction in $\mathrm{NO}_{2}$ photolysis rates and subsequently in surface ozone mixing ratios (Jo et al., 2016). Jo et al. (2016) reported that, on an annual average basis, changes in surface ozone mixing ratios related to brown carbon aerosol absorption over south Asia are $<5 \%$. Further studies should be done in the future to investigate the impact of aerosols on surface ozone, also with regional models like WRF-Chem. The current and other modelling efforts, constrained by limited measurement data, stress the need for more comprehensive observations, e.g. in a network of stations, and making the data available through projects such as TOAR (http://toar-data.fz-juelich.de/). Our study highlights the need to also evaluate $\mathrm{O}_{3}$ precursors, similar to that conducted here for ozone, to further reduce uncertainties in modelled ozone over south Asia for the better assessment of implications of surface ozone on public health and crop yield. In order to make better model predictions at further higher resolution (than $12 \mathrm{~km}$ ), development of finer-resolution inventories than the ones used in the current study is also required over the region. Thus, we also recommend preparing highresolution regional inventories for the anthropogenic emissions of $\mathrm{O}_{3}$ precursors over south Asia, also accounting for year-to-year changes.

Data availability. The model output from all the numerical simulations is available at the MPG supercomputer HYDRA (http:// www.mpcdf.mpg.de/services/computing/hydra) and is provided by contacting the corresponding authors. The observed values shown for comparison are from previous papers with a complete list of references provided in Table 4 . New observations for the Delhi and Pune stations are available from the SAFAR programme (http: //safar.tropmet.res.in/).

The Supplement related to this article is available online at https://doi.org/10.5194/acp-17-14393-2017supplement.
Acknowledgements. Amit Sharma acknowledges the fellowship from the Max Planck Institute for Chemistry (MPI-C) to carry out this study. Sachin S. Gunthe acknowledges the support from DST-Max Planck partner group at IIT Madras and Ministry of Earth Sciences (MoES), Government of India. Model simulations have been performed on the MPG supercomputer HYDRA (http://www.mpcdf.mpg.de/services/computing/hydra). Initial and boundary condition data for meteorological fields were obtained from the ECMWF website (http: //www.ecmwf.int/en/research/climate-reanalysis/era-interim).

The HTAP v2 anthropogenic emissions were obtained from http://edgar.jrc.ec.europa.eu/htap_v2/index.php?SECURE=123.

The authors are grateful to Yafang Cheng (MPI-C) for providing SEAC4RS emission. The INTEX-B anthropogenic emissions were obtained from http://bio.cgrer.uiowa.edu/EMISSION_DATA_new/ data/intex-b_emissions/. MOZART-4/GEOS5 output used as initial and boundary conditions for chemical fields is acknowledged. The preprocessors and inputs for biogenic and biomass-burning emissions were obtained from the NCAR Atmospheric Chemistry website (www.acom.ucar.edu/wrf-chem/download.shtml). Radiosonde data of water vapour mixing ratio, temperature and wind speed were obtained from the University of Wyoming website (http://weather.uwyo.edu/upperair/sounding.html). The authors are also thankful for the use of HPC supercluster and to the staff at the P. G. Senapathy Computer Center at IIT Madras. Constructive comments and suggestions from two anonymous reviewers and the handling editor, William Bloss, are gratefully acknowledged.

The article processing charges for this open-access publication were covered by the Max Planck Society.

Edited by: William Bloss

Reviewed by: two anonymous referees

\section{References}

Ackermann, I. J., Hass, H., Memmesheimer, M., Ebel, A., Binkowski, F. S., and Shankar, U.: Modal aerosol dynamics model for Europe: development and first applications, Atmos. Environ., 32, 2981-2999, https://doi.org/10.1016/S13522310(98)00006-5, 1998.

Ainsworth, E. A., Yendrek, C. R., Sitch, S., Collins, W. J., and Emberson, L. D.: The effects of tropospheric ozone on net primary productivity and implications for climate change, Annu. Rev. Plant Biol., 63, 637-661, 2012.

Akimoto, H.: Global air quality and pollution, Science, 302, 17161719, https://doi.org/10.1126/science.1092666, 2003.

Alexander, D. T. L., Crozier, P. A., and Anderson, J. R.: Brown carbon spheres in East Asian outflow and their optical properties, Science, 321, 833-836, https://doi.org/10.1126/science.1155296, 2008.

Amnuaylojaroen, T., Barth, M. C., Emmons, L. K., Carmichael, G. R., Kreasuwun, J., Prasitwattanaseree, S., and Chantara, S.: Effect of different emission inventories on modeled ozone and carbon monoxide in Southeast Asia, Atmos. Chem. Phys., 14, 12983-13012, https://doi.org/10.5194/acp-14-12983-2014, 2014. 
Anenberg, S. C., Horowitz, L. W., Tong, D. Q., and West, J. J.: An estimate of the global burden of anthropogenic ozone and fine particulate matter on premature human mortality using atmospheric modelling, Environ. Health Persp., 118, 1189-1195, 2010.

Ansari, T. U., Ojha, N., Chandrasekar, R., Balaji, C., Singh, N., and Gunthe, S. S.: Competing impact of anthropogenic emissions and meteorology on the distribution of trace gases over Indian region, J. Atmos. Chem., 73, 363-380, https://doi.org/10.1007/s10874016-9331-y, 2016.

Atkinson, R.: Atmospheric chemistry of VOCs and $\mathrm{NO}_{x}$, Atmos. Environ., 34, 2063-2101, https://doi.org/10.1016/S13522310(99)00460-4, 2000.

Barth, M. C., Lee, J., Hodzic, A., Pfister, G., Skamarock, W. C., Worden, J., Wong, J., and Noone, D.: Thunderstorms and upper troposphere chemistry during the early stages of the 2006 North American Monsoon, Atmos. Chem. Phys., 12, 11003-11026, https://doi.org/10.5194/acp-12-11003-2012, 2012.

Beig, G., Gunthe, S., and Jadhav, D. B.: Simultaneous measurements of ozone and its precursors on a diurnal scale at a semi urban site in India, J. Atmos. Chem., 57, 239-253, https://doi.org/10.1007/s10874-007-9068-8, 2007.

Bell, M. L., McDermott, A., Zeger, S. L., Samet, J. M., and Dominici, F.: Ozone and short term mortality in 95 US urban communities, 1987-2000, JAMA-J. Am. Med. Assoc., 292, 23722378, 2004.

Bhuyan, P. K., Bharali, C., Pathak, B., and Kalita, G.: The role of precursor gases and meteorology on temporal evolution of $\mathrm{O}_{3}$ at a tropical location in northeast India, Environ. Sci. Pollut. R., 21, 6696-6713, 2014.

Carmichael, G. R., Sakurai, T., Streets, D., Hozumi, Y., Ueda, H., Park, S. U., Funge, C., Han, Z., Kajino, M., Engardt, M., Bennet, C., Hayami, H., Sartelet, K., Holloway, T., Wang, Z., Kannari, A., Fu, J., Matsuda, K., Thongboonchoo, N., and Amann, M.: MICS-Asia II: the model intercomparison study for Asia Phase II methodology and overview of findings, Atmos. Environ., 42, 3468-3490, https://doi.org/10.1016/j.atmosenv.2007.04.007, 2008.

Chin, M., Rood, R. B., Lin, S.-J., Muller, J. F., and Thomspon, A. M.: Atmospheric sulfur cycle in the global model GOCART: model description and global properties, J. Geophys. Res., 105, 24671-24687, 2000.

Chou, M. -D. and Suarez, M. J.: An efficient thermal infrared radiation parameterization for use in general circulation models, NASA Technical Memorandum 104606, 3, 85 pp., NASA, Goddard Space Flight Center, Greenbelt, Maryland, 1994.

Cox, R. A., Eggleton, A. E. J., Derwent, R. G., Lovelock, J. E., and Pack, D. H.: Long-range transport of photochemical ozone in north-western Europe, Nature, 255, 118-121, https://doi.org/10.1038/255118a0, 1975.

Crutzen, P. J.: Photochemical reactions initiated by and influencing ozone in unpolluted tropospheric air, Tellus, 26, 47-57, 1974.

David, L. M. and Nair, P. R.: Diurnal and seasonal variability of surface ozone and $\mathrm{NO}_{x}$ at a tropical coastal site: association with mesoscale and synoptic meteorological conditions, J. Geophys. Res., 116, D10303, https://doi.org/10.1029/2010JD015076, 2011.

Debaje, S. B. and Kakade, A. D.: Measurements of Surface Ozone in Rural Site of India, Aerosol Air Qual. Res., 6, 444-465, 2006.
Emberson, L. D., Buker, P., Ashmore, M., Mills, G., Jackson, L., Agrawal, M., Atikuzzaman, M., Cinderby, S., Engardt, M., Jamir, C., Kobayashi, K., Oanh, N., Quadir, Q., and Wahid, A.: A comparison of North-American and Asian exposure-response data for ozone effects on crop yields, Atmos. Environ., 43, 19451953, 2009.

Emmons, L. K., Walters, S., Hess, P. G., Lamarque, J.-F., Pfister, G. G., Fillmore, D., Granier, C., Guenther, A., Kinnison, D., Laepple, T., Orlando, J., Tie, X., Tyndall, G., Wiedinmyer, C., Baughcum, S. L., and Kloster, S.: Description and evaluation of the Model for Ozone and Related chemical Tracers, version 4 (MOZART-4), Geosci. Model Dev., 3, 43-67, https://doi.org/10.5194/gmd-3-43-2010, 2010.

Fast, J. D., Gustafson Jr., W. I., Easter, R. C., Zaveri, R. A., Barnard, J. C., Chapman, E. G., Grell, G. A., and Peckham, S. E.: Evolution of ozone, particulates, and aerosol direct radiative forcing in the vicinity of Houston using a fully-coupled meteorology-chemistry aerosol model, J. Geophys. Res., 111, D21305, 2006.

Gaur, A., Tripathi, S. N., Kanawade, V. P., Tare, V., and Shukla, S. P.: Four-year measurements of trace gases $\left(\mathrm{SO}_{2}, \mathrm{NO}_{x}\right.$, $\mathrm{CO}$, and $\mathrm{O}_{3}$ ) at an urban location, Kanpur, in Northern India, J. Atmos. Chem., 71, 283-301, 2014.

Geng, F., Zhao, C., Tang, X., Lu, G., and Tie, X.: Analysis of ozone and VOCs measured in Shanghai: a case study, Atmos. Environ., 41, 989-1001, 2007.

Ghude, S. D., Jena, C., Chate, D. M., Beig, G., Pfister, G. G., Kumar, R., and Ramanathan, V.: Reduction in India's crop yield due to ozone, Geophys. Res. Lett., 41, 51971, https://doi.org/10.1002/2014GL060930, 2014.

Ghude, S. D., Chate, D. M., Jena, C., Beig, G., Kumar, R., Barth, M. C., PFister, G. G., Fadnavis, S. and Pithani, P.: Premature mortality in India due to $\mathrm{PM}_{2.5}$ and ozone exposure, Geophys. Res. Lett., 43, 4650-4658, 2016.

Girach, I. A., Ojha, N., Nair, P. R., Pozzer, A., Tiwari, Y. K., Kumar, K. R., and Lelieveld, J.: Variations in $\mathrm{O}_{3}, \mathrm{CO}$, and $\mathrm{CH}_{4}$ over the Bay of Bengal during the summer monsoon season: shipborne measurements and model simulations, Atmos. Chem. Phys., 17, 257-275, https://doi.org/10.5194/acp-17-257-2017, 2017.

Grell, G.: Prognostic evaluation of assumptions used by cumulus parameterizations, Mon. Weather Rev., 121, 764-787, 1993.

Grell, G. and Devenyi, D.: A generalized approach to parameterizing convection combining ensemble and data assimilation techniques, Geophys. Res. Lett., 29, 38-31, 2002.

Grell, G. A., Peckham, S. E., McKeen, S., Schmitz, R., Frost, G., Skamarock, W. C., and Eder, B.: Fully coupled "online" chemistry within the WRF model, Atmos. Environ., 39, 6957-6975, 2005.

Guenther, A., Karl, T., Harley, P., Wiedinmyer, C., Palmer, P. I., and Geron, C.: Estimates of global terrestrial isoprene emissions using MEGAN (Model of Emissions of Gases and Aerosols from Nature), Atmos. Chem. Phys., 6, 3181-3210, https://doi.org/10.5194/acp-6-3181-2006, 2006.

Gupta, M. and Mohan, M.: Validation of WRF/Chem model and sensitivity of chemical mechanisms to ozone simulation over megacity Delhi, Atmos. Environ., 122, 220-229, 2015.

Gurjar, B. R., Ravindra, K., and Nagpure, A. S.: Air pollution trends over Indian megacities and their local- 
to-global implications, Atmos. Environ., 142, 475-495, https://doi.org/10.1016/j.atmosenv.2016.06.030, 2016.

Hecobian, A., Zhang, X., Zheng, M., Frank, N., Edgerton, E. S., and Weber, R. J.: Water-Soluble Organic Aerosol material and the light-absorption characteristics of aqueous extracts measured over the Southeastern United States, Atmos. Chem. Phys., 10, 5965-5977, https://doi.org/10.5194/acp-10-5965-2010, 2010.

Jain, S. L., Arya, B. C., Kumar, A., Ghude, S. D., and Kulkarni, P. S.: Observational study of surface ozone at New Delhi, India, Int. J. Remote Sens., 26, 3515-3524, 2005.

Janjic, Z. I.: The step-mountain eta coordinate model: further developments of the convection, viscous sublayer and turbulence closure schemes, Mon. Weather Rev., 122, 927-945, 1994.

Janjic, Z. I.: The surface layer in the NCEP Eta Model, Eleventh Conference on Numerical Weather Prediction, Norfolk, VA, 1923 August; American Meteorological Society, Boston, MA, 354355,1996

Janjic, Z. I.: Nonsingular Implementation of the Mellor-Yamada Level 2.5 Scheme in the NCEP Meso model, NCEP Office Note, No. 437, 61 pp., National Centers for Environmental Prediction, USA, 2002.

Janssens-Maenhout, G., Crippa, M., Guizzardi, D., Dentener, F., Muntean, M., Pouliot, G., Keating, T., Zhang, Q., Kurokawa, J., Wankmüller, R., Denier van der Gon, H., Kuenen, J. J. P., Klimont, Z., Frost, G., Darras, S., Koffi, B., and Li, M.: HTAP_v2.2: a mosaic of regional and global emission grid maps for 2008 and 2010 to study hemispheric transport of air pollution, Atmos. Chem. Phys., 15, 11411-11432, https://doi.org/10.5194/acp-15-11411-2015, 2015.

Jena, C., Ghude, S. D., Pfister, G. G., Chate, D. M., Kumar, R., Beig, G., Surendran, D., Fadnavis, S., and Lal, D. M.: Influence of springtime biomass burning emissions in South Asia on regional ozone: a model based case study, Atmos. Environ., 100, 37-47, https://doi.org/10.1016/j.atmosenv.2014.10.027, 2014.

Jena, C., Ghude, S. D., Beig, G., Chate, D. M., Kumar, R., Pfister, G. G., Lal, D. M., Surendran, D. E., Fadnavis, S., and van der, A. R. J.: Inter-comparison of different $\mathrm{NO}_{x}$ emission inventories and associated variation in simulated surface ozone in Indian region, Atmos. Environ., 117, 61-73, 2015.

Jerrett, M., Burnett, R. T., Pope, C. A., Ito, K., Thurston, G., Krewski, D., Shi, Y. L., Calle, E., and Thun, M.: Long-Term Ozone Exposure and Mortality, New England J. Med., 360, 1085-1095, https://doi.org/10.1056/NEJMoa0803894, 2009.

Jo, D. S., Park, R. J., Lee, S., Kim, S.-W., and Zhang, X.: A global simulation of brown carbon: implications for photochemistry and direct radiative effect, Atmos. Chem. Phys., 16, 3413-3432, https://doi.org/10.5194/acp-16-3413-2016, 2016.

Kirchstetter, T. W. and Thatcher, T. L.: Contribution of organic carbon to wood smoke particulate matter absorption of solar radiation, Atmos. Chem. Phys., 12, 6067-6072, https://doi.org/10.5194/acp-12-6067-2012, 2012.

Kirchstetter, T. W., Novakov, T., and Hobbs, P. V.: Evidence that the spectral dependence of light absorption by aerosols is affected by organic carbon, J. Geophys. Res., 109, D21208, https://doi.org/10.1029/2004JD004999, 2004.

Kleinman, L., Lee, Y.-N., Springston, S. R., Nunnermacker, L., Zhou, X., Brown, R., Hallock, K., Klotz, P., Leahy, D., Lee, J. H., and Newman, L.: Ozone formation at a rural site in the south- eastern United States, J. Geophys. Res.-Atmos., 99, 3469-3482, https://doi.org/10.1029/93JD02991, 1994.

Kleinman, L. I., Daum, P. H., Lee, Y.-N., Nunnermacker, L. J., Springston, S. R., Weinstein-Lloyd, J., Hyde, P., Doskey, P., Rudolph, J., Fast, J., and Berkowitz, C.: Photochemical age determinations in the Phoenix metropolitan area, J. Geophys. Res., 108, 4096, https://doi.org/10.1029/2002JD002621, 2003.

Krupa, S. V., Nosal, M., and Legge, A. H.: A numerical analysis of the combined open top chamber data from the USA and Europe on ambient ozone and negative crop responses, Environ. Pollut., 101, 157-160, 1998.

Kumar, R., Naja, M., Venkataramani, S., and Wild, O.: Variations in surface ozone at Nainital: a high-altitude site in the central Himalayas, J. Geophys. Res., 115, D16302, https://doi.org/10.1029/2009JD013715, 2010.

Kumar, R., Naja, M., Pfister, G. G., Barth, M. C., and Brasseur, G. P.: Simulations over South Asia using the Weather Research and Forecasting model with Chemistry (WRF-Chem): set-up and meteorological evaluation, Geosci. Model Dev., 5, 321-343, https://doi.org/10.5194/gmd-5-321-2012, 2012a.

Kumar, R., Naja, M., Pfister, G. G., Barth, M. C., Wiedinmyer, C., and Brasseur, G. P.: Simulations over South Asia using the Weather Research and Forecasting model with Chemistry (WRF-Chem): chemistry evaluation and initial results, Geosci. Model Dev., 5, 619-648, https://doi.org/10.5194/gmd-5-6192012, 2012b.

Kumar, R., Barth, M. C., Pfister, G. G., Nair, V. S., Ghude, S. D., and Ojha, N.: What controls the seasonal cycle of black carbon aerosols in India?, J. Geophys. Res. Atmos., 120, 7788-7812, https://doi.org/10.1002/2015JD023298, 2015.

Lawrence, M. G., Rasch, P. J., von Kuhlmann, R., Williams, J., Fischer, H., de Reus, M., Lelieveld, J., Crutzen, P. J., Schultz, M., Stier, P., Huntrieser, H., Heland, J., Stohl, A., Forster, C., Elbern, H., Jakobs, H., and Dickerson, R. R.: Global chemical weather forecasts for field campaign planning: predictions and observations of large-scale features during MINOS, CONTRACE, and INDOEX, Atmos. Chem. Phys., 3, 267-289, https://doi.org/10.5194/acp-3-267-2003, 2003.

Lawrence, M. G. and Lelieveld, J.: Atmospheric pollutant outflow from southern Asia: a review, Atmos. Chem. Phys., 10, 1101711096, https://doi.org/10.5194/acp-10-11017-2010, 2010.

Lelieveld, J. and Dentener, F. J.: What controls tropospheric ozone?, J. Geophys. Res., 105, 3531-3551, 2000.

Lelieveld, J., Berresheim, H., Borrmann, S., Crutzen, P. J., Dentener, F. J., Fischer, H., Feichter, J., Flatau, P. J., Heland, J., Holzinger, R., Korrmann, R., Lawrence, M. G., Levin, Z., Markowicz, K. M., Mihalopoulos, N., Minikin, A., Ramanathan, V., de Reus, M., Roelofs, G. J., Scheeren, H. A., Sciare, J., Schlager, H., Schultz, M., Siegmund, P., Steil, B., Stephanou, E. G., Stier, P., Traub, M., Warneke, C., Williams, J., and Ziereis, H.: Global air pollution crossroads over the Mediterranean, Science, 298, 794-799, https://doi.org/10.1126/science.1075457, 2002.

Lelieveld, J., Evans, J. S., Fnais, M., Giannadaki, D., and Pozzer, A.: The contribution of outdoor air pollution sources to premature mortality on a global scale, Nature, 525, 367-371, 2015.

Lin, Y.-L., Farley, R. D., and Orville, H. D.: Bulk parameterization of the snow field in a cloud model, J. Clim. Appl. Meteorol., 22, 1065-1092, 1983. 
Liu, Y., Warner, T. T., Bowers, J. F., Carson, L. P., Chen, F., Clough, C. A., Davis, C. A., Egeland, C. H., Halvorson, S., Huck Jr., T. W., Lachapelle, L., Malone, R. E., Rife, D. L., Sheu, R., - S., Swerdlin, S. P., and Weingarten, D. S.: The operational mesogamma-scale analysis and forecast system of the US Army Test and Evaluation Command. Part 1: Overview of the modeling system, the forecast products, J. Appl. Meteorol. Clim., 47, 1077-1092, 2008.

Logan, J. A., Staehelin, J., Megretskaia, I. A., Cammas, J.-P., Thouret, V., Claude, H., De Backer, H., Steinbacher, M., Scheel, H.-E., Stubi, R., Frohlich, M., and Derwent, R.: Changes in ozone over Europe: analysis of ozone measurements from sondes, regular aircraft (MOZAIC) and alpine surface sites, J. Geophys. Res., 117, D09301, https://doi.org/10.1029/2011JD016952, 2012.

Lu, Z. and Streets, D. G.: The Southeast Asia Composition, Cloud, Climate Coupling Regional Study Emission Inventory, available at: http://bio.cgrer.uiowa.edu/SEAC4RS/html/ (last access: 2 December 2017), 2012.

Lüthi, Z. L., Škerlak, B., Kim, S.-W., Lauer, A., Mues, A., Rupakheti, M., and Kang, S.: Atmospheric brown clouds reach the Tibetan Plateau by crossing the Himalayas, Atmos. Chem. Phys., 15, 6007-6021, https://doi.org/10.5194/acp-156007-2015, 2015.

Mahapatra, P. S., Jena, J., Moharana, S., Srichandan, H., Das, T., Roy, C. G., and Das, S. N.: Surface ozone variation at Bhubaneswar and intra-corelationship study with various parameters, J. Earth Syst. Sci., 121, 1163-1175, 2012.

Mallik, C., Lal, S., and Venkataramani, S.: Trace gases at a semi-arid urban site in western India: variability and intercorrelations, J. Atmos. Chem., 72, 143-164, 2015.

Mar, K. A., Ojha, N., Pozzer, A., and Butler, T. M.: Ozone air quality simulations with WRF-Chem (v3.5.1) over Europe: model evaluation and chemical mechanism comparison, Geosci. Model Dev., 9, 3699-3728, https://doi.org/10.5194/gmd-9-3699-2016, 2016.

Mellor, G. L. and Yamada, T.: Development of a turbulence closure model for geophysical fluid problems, Rev. Geophys. Space Ge., 20, 851-875, 1982.

Michael, M., Yadav, A., Tripathi, S. N., Kanawade, V. P., Gaur, A., Sadavarte, P., and Venkataraman, C.: Simulation of trace gases and aerosols over the Indian domain: evaluation of the WRF-Chem Model, Atmos. Chem. Phys. Discuss., https://doi.org/10.5194/acpd-13-12287-2013, in review, 2013.

Mlawer, E. J., Taubman, S. J., Brown, P. D., Iacono, M. J., and Clough, S. A.: Radiative transfer for inhomogeneous atmosphere: RRTM, a validated correlated-k model for the long-wave, J. Geophys. Res., 102, 16663-16682, 1997.

Monin, A. S. and Obukhov, A. M.: Basic laws of turbulent mixing in the surface layer of the atmosphere, Tr. Geofiz. Inst., Akad. Nauk SSSR, 24, 163-187, 1954.

Monks, P. S., Archibald, A. T., Colette, A., Cooper, O., Coyle, M., Derwent, R., Fowler, D., Granier, C., Law, K. S., Mills, G. E., Stevenson, D. S., Tarasova, O., Thouret, V., von Schneidemesser, E., Sommariva, R., Wild, O., and Williams, M. L.: Tropospheric ozone and its precursors from the urban to the global scale from air quality to short-lived climate forcer, Atmos. Chem. Phys., 15, 8889-8973, https://doi.org/10.5194/acp-15-8889-2015, 2015.
Nishanth, T., Praseed, K. M., Satheesh Kumar, M. K., and Valsaraj, K. T.: Analysis of ground level $\mathrm{O}_{3}$ and $\mathrm{NO}_{x}$ Measured at Kannur, India, J. Earth Sci. Clim. Change, 3, 111, https://doi.org/10.4172/2157-7617.1000111, 2012.

Ohara, T., Akimoto, H., Kurokawa, J., Horii, N., Yamaji, K., Yan, X., and Hayasaka, T.: An Asian emission inventory of anthropogenic emission sources for the period 1980-2020, Atmos. Chem. Phys., 7, 4419-4444, https://doi.org/10.5194/acp-7-44192007, 2007.

Ojha, N., Naja, M., Singh, K. P., Sarangi, T., Kumar, R., Lal, S., Lawrence, M. G., Butler, T. M., and Chandola, H. C.: Variabilities in ozone at a semi-urban site in the Indo-Gangetic Plain region: association with the meteorology and regional process, J. Geophys. Res., 117, D20301, https://doi.org/10.1029/2012JD017716, 2012.

Ojha, N., Naja, M., Sarangi, T., Kumar, R., Bhardwaj, P., Lal, S., Venkataramani, S., Sagar, R., Kumar, A., and Chandola, H. C.: On the processes influencing the vertical distribution of ozone over the central Himalayas: analysis of yearlong ozonesonde observations, Atmos. Environ., 88, 201-211, https://doi.org/10.1016/j.atmosenv.2014.01.031, 2014.

Ojha, N., Pozzer, A., Rauthe-Schöch, A., Baker, A. K., Yoon, J., Brenninkmeijer, C. A. M., and Lelieveld, J.: Ozone and carbon monoxide over India during the summer monsoon: regional emissions and transport, Atmos. Chem. Phys., 16, 3013-3032, https://doi.org/10.5194/acp-16-3013-2016, 2016.

Otte, T. L.: The impact of nudging in the meteorological model for retrospective air quality simulations. Part I: Evaluation against national observation networks, J. Appl. Meteorol. Clim., 47, 1853-1867, 2008.

Pozzer, A., Zimmermann, P., Doering, U. M., van Aardenne, J., Tost, H., Dentener, F., Janssens-Maenhout, G., and Lelieveld, J.: Effects of business-as-usual anthropogenic emissions on air quality, Atmos. Chem. Phys., 12, 6915-6937, https://doi.org/10.5194/acp-12-6915-2012, 2012.

Reddy, B. S. K., Kumar, K. R., Balakrishnaiah, G., Gopal, K. R., Reddy, R. R., Ahammed, Y. N., Narasimhulu, K., Reddy, L. S. S., and Lal, S.: Observational studies on the variations in surface ozone concentration at Anantapur in southern India, Atmos. Res., 98, 125-139, 2010.

Renuka, K., Gadhavi, H., Jayaraman, A., Lal, S., Naja, M., and Rao, S.: Study of Ozone and $\mathrm{NO}_{2}$ over Gadanki a rural site in South India, J. Atmos. Chem., 71, 95-112, https://doi.org/10.1007/s10874-014-9284-y, 2014.

Sarangi, T., Naja, M., Ojha, N., Kumar, R., Lal, S., Venkataramani, S., Kumar, A., Sagar, R., and Chandola, H. C.: First simultaneous measurements of ozone, $\mathrm{CO}$ and $\mathrm{NO}_{y}$ at a high altitude regional representative site in the central Himalayas, J. Geophys. Res.-Atmos., 119, 1592-1611, https://doi.org/10.1002/2013JD020631, 2014.

Sarkar, M., Venkataraman, C., Guttikunda, S., and Sadavarte, P.: Indian emissions of technology-linked NMVOCs with chemical speciation: an evaluation of the SAPRC99 mechanism with WRF-CAMx simulations, Atmos. Environ., 134, 70-83, https://doi.org/10.1016/j.atmosenv.2016.03.037, 2016.

Sarkar, S., Srivastava, R. K., and Sagar, K.: Diurnal monitoring of surface ozone and $\mathrm{PM}_{2.5}$ concentration and its correlation with temperature, International Journal of Technology Enhancements and Emerging Engineering Research, 3, 121-129, 2015. 
Schell, B., Ackermann, I. J., Hass, H., Binkowski, F. S., and Ebel, A.: Modeling the formation of secondary organic aerosol within a comprehensive air quality model system, J. Geophys. Res.-Atmos., 106, 28275-28293, https://doi.org/10.1029/2001JD000384, 2001.

Sillman, S.: The use of $\mathrm{NO}_{y}, \mathrm{H}_{2} \mathrm{O}_{2}$ and $\mathrm{HNO}_{3}$ as indicators for ozone- $\mathrm{NO}_{x}$-hydrocarbon sensitivity in urban locations, J. Geophys. Res., 100, 14175-14188, 1995.

Sinha, V., Kumar, V., and Sarkar, C.: Chemical composition of premonsoon air in the Indo-Gangetic Plain measured using a new air quality facility and PTR-MS: high surface ozone and strong influence of biomass burning, Atmos. Chem. Phys., 14, 59215941, https://doi.org/10.5194/acp-14-5921-2014, 2014

Stauffer, D. R. and Seaman, N. L.: Use of four-dimensional data assimilation in a limited area mesoscale model. Part I: Experiments with synoptic-scale data, Mon. Weather Rev., 118, 1250-1277, 1990.

Stauffer, D. R., Seaman, N. L., and Binkowski, F. S.: Use of fourdimensional data assimilation in a limited-area mesoscale model. Part II: Effects of data assimilation within the planetary boundary layer, Mon. Weather Rev., 119, 734-754, 1991.

Stockwell, W. R., Middleton, P., Chang, J. S., and Tang, X.: The second generation regional acid deposition model chemical mechanism for regional air quality modeling, J. Geophys. Res., 95, 16343-16367, 1990.

Taylor, K. E.: Summarizing multiple aspects of model performance in a single diagram, J. Geophys. Res., 106, 7183-7192, 2001.

Tewari, M., Chen, F., Wang, W., Dudhia, J., Lemone, M. A., Mitchell, K. E., Ek, M., Gayno, G., Wegiel, J. W., and Cuenca, R.: Implementation and verification of the unified Noah land-surface model in the WRF model, 20th Conference on Weather Analysis and Forecasting/16th Conference on Numerical Weather Prediction (14 January 2004), Seattle, WA, American Meteorological Society, 11-15, 2004.

Tie, X., Geng, F., Guenther, A., Cao, J., Greenberg, J., Zhang, R., Apel, E., Li, G., Weinheimer, A., Chen, J., and Cai, C.: Megacity impacts on regional ozone formation: observations and WRFChem modeling for the MIRAGE-Shanghai field campaign, Atmos. Chem. Phys., 13, 5655-5669, https://doi.org/10.5194/acp13-5655-2013, 2013.
Wiedinmyer, C., Akagi, S. K., Yokelson, R. J., Emmons, L. K., AlSaadi, J. A., Orlando, J. J., and Soja, A. J.: The Fire INventory from NCAR (FINN): a high resolution global model to estimate the emissions from open burning, Geosci. Model Dev., 4, 625641, https://doi.org/10.5194/gmd-4-625-2011, 2011.

Wild, O., Zhu, X., and Prather, M. J.: Fast-J: accurate simulation of in- and below cloud photolysis in tropospheric chemical models, J. Atmos. Chem., 37, 245-282, 2000.

Wilkinson, S., Mills, G., Illidge, R., and Davies, W. J.: How is ozone pollution reducing our food supply?, J. Exp. Bot., 63, 527-536, https://doi.org/10.1093/jxb/err317, 2012.

Yadav, R., Sahu, L. K., Jaaffrey, S. N. A., and Beig, G.: Distributions of ozone and related trace gases at an urban site in western India, J. Atmos. Chem., 71, 125-144, 2014.

Yang, M., Howell, S. G., Zhuang, J., and Huebert, B. J.: Attribution of aerosol light absorption to black carbon, brown carbon, and dust in China - interpretations of atmospheric measurements during EAST-AIRE, Atmos. Chem. Phys., 9, 2035-2050, https://doi.org/10.5194/acp-9-2035-2009, 2009.

Yoon, J. and Pozzer, A.: Model-simulated trend of surface carbon monoxide for the 2001-2010 decade, Atmos. Chem. Phys., 14, 10465-10482, https://doi.org/10.5194/acp-14-10465-2014, 2014.

Zanis, P., Hadjinicolaou, P., Pozzer, A., Tyrlis, E., Dafka, S., Mihalopoulos, N., and Lelieveld, J.: Summertime free-tropospheric ozone pool over the eastern Mediterranean/Middle East, Atmos. Chem. Phys., 14, 115-132, https://doi.org/10.5194/acp-14-1152014, 2014.

Zaveri, R. A. and Peters, L. K.: A new lumped structure photochemical mechanism for large-scale applications, J. Geophys. Res. 104, 30387-30415, 1999.

Zhang, Q., Streets, D. G., Carmichael, G. R., He, K. B., Huo, H., Kannari, A., Klimont, Z., Park, I. S., Reddy, S., Fu, J. S., Chen, D., Duan, L., Lei, Y., Wang, L. T., and Yao, Z. L.: Asian emissions in 2006 for the NASA INTEX-B mission, Atmos. Chem. Phys., 9, 5131-5153, https://doi.org/10.5194/acp-9-5131-2009, 2009. 